\title{
GLASCOW
}

The Castric Caeca \& the

Caecal Bacteria of Heteroptera

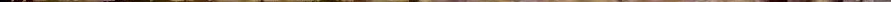


THE UNIVERSITY

OF ILLINOIS

LIBRARY

1913

G46 



\section{THE GASTRIC CAECA AND THE CAECAL BACTERIA OF HETEROPTERA}

BY

HUGH ĠLASGOW

A. B. University of Illinois

1908.

\section{THESIS}

Submitted in Partial Fulfillment of the Requirements for the

Degree of

DOCTOR OF PHILOSOPHY

IN ENTOMOLOGY

IN

THE GRADUATE SCHOOL

OF THE

UNIVERSITY OF ILLINOIS

1913 



\section{UNIVERSITY OF ILLINOIS \\ THE GRADUATE SCHOOL}

$$
\text { may } 17,1913
$$

I HEREBY RECOMMEND THAT THE THESIS PREPARED UNDER MY SUPERVISION BY

Hugh Glasgow

ENTITLED - The Intestinal vaeca and the daecal Bacteria of

He teroptera

BE ACCEPTED AS FULFILLING THIS PART OF THE REQUIREMENTS FOR THE

DEGREE OF Doctor of Philosophy.

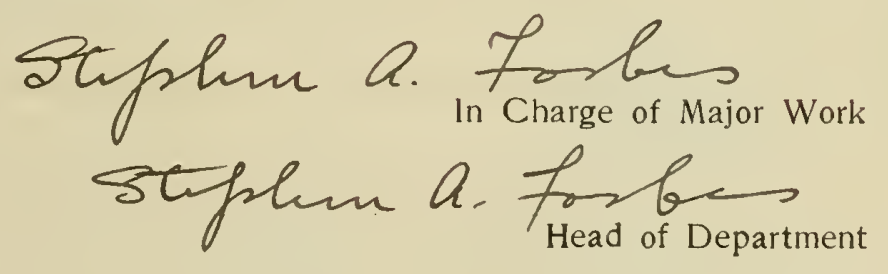

Recommendation concurred in:

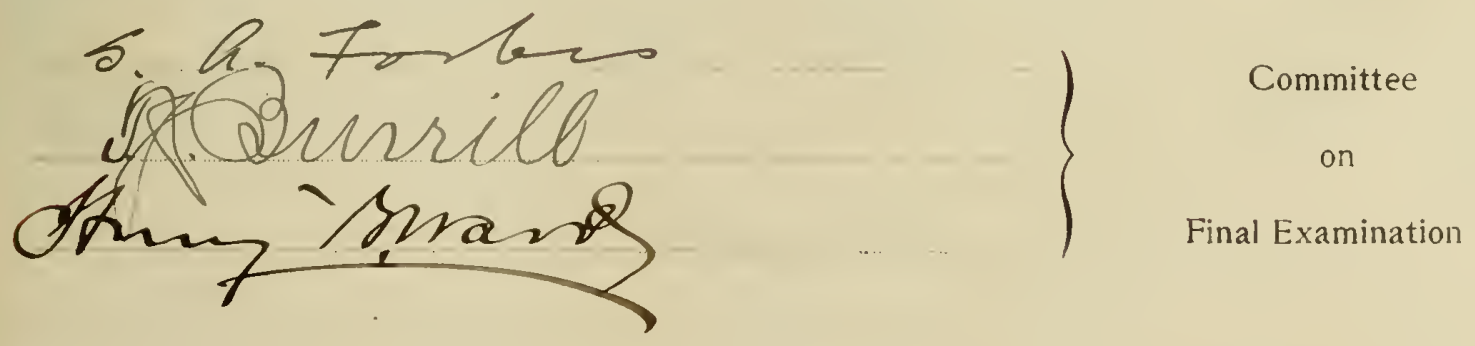



TABLE OF CONTENTS

I. Introduction

II. Function and Phylogenetic Significance of the Caeca in the Heteroptera

III. Constancy of the Caecal Infection

IV. Cultivation of the Caecal Bacteria

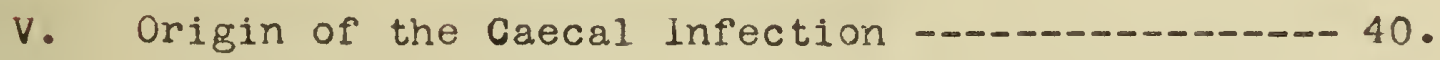

VI. Functional Relation of the Caecal Bacteria

to the Host Insect $\ldots \ldots$

VII. Importance of the "Normal" Intestinal

Bacteria to the Host

VIII.Summary _... 73.

IX. Bingraphy - 
Digitized by the Internet Archive in 2014

http://archive.org/details/gastriccaecacaec00glas 
INTRODUCTION

In certain groups of Heteroptera the alimentary canal is characterized by the presence of peculiar sac-like appendages which open into the mid intestine at its extreme postericr end. These structures vary greatly in form and in degree of development in the different families in which they occur, but all have essentially the same histological structure and all agree in the fact that they invariably contain great masses of bacteria, apparently in pure culture, which are morphologically characteristic for the families and often for the genera in which they occur.

These structures were noted as early as 1809 by Treviranus in a pentatomid, Pentatoma rufipes (Cimex rufipes), and again in 1811 by Ramdohr in Pyrrhocoris apterus as well as in representatives of the Pentatomidae, and they were subsequently observed and studied by numerous other investigators, notably by Dufour in 1833. It was not until about 1888, however, that Professor S. A. Forbes, in the course of an elaborate series of investigations on the contagious diseases of insects, discovered the remarkable association existing between certain Heteroptera and the bacteria which he found uniformly inhabiting the so-called caecal glands. Leydig had previously noted the presence of these organisms in the caecal appendages of a pentatomid in 1857 , but he did 
$+$

, 10 
not suggest their true nature and merely expressed surprise at the occurrence of such unusual structures in these organs. These caecal bacteria were really first observed by Professor Forbes in 1882 in crushed specimens of the Chinch Bug, Blissus leucopterus, and a brief technical description of the organism, under the name Micrococcus insectorum, was given it by Professor T. J. Burrill in 1883. The specimens first examined by Professor Forbes were from experimental cages of potted corn in which the insects had been dying in large numbers from some cause which even at the present time is not clearly understood, and upon finding large numbers of specific bacteria in crushed preparations of these insects he at first very naturally regarded them as the probable cause of the trouble, and proceeded to investigate the matter with characteristic thoroughness, with a view to the possible utilization of this organism as a means of controlling the chinch bug in the field. After a careful study, however, he was finally forced to the conclusion that the bacteria were not parasitic upon the chinch bug at all, but that they were really normal to the caecal appendages of healthy bugs and that they probably had some important function in the metabolism of the insect. He also established later, by the examination of a great variety of insects of different orders, and especially of Heteroptera, the fact that the chinch bug was not unique in this regard, but that the same 
phenomenon also occurred in a number of other species of Lygaeidae as well as in representatives of several other families of Heteroptera, and that wherever the caeca were present in this group, they were always fillod with specific bacteria. A large part of this work was never published and the unpublished notes, which proved to be of the greatest assistance in this work, were turned over to me by Professor Forbes for use in continuing a study of the subject. The problom as it was suggested to me by Professor Forbes was primarily to determine the significance of the presence of these "normal" bacteria of the caeca -- to work out, if possible, the relation existing between the insects and their characteristic intestinal flora, and also, indirect1y to determine whether the occurrence of these complex caecal structures might not throw some light on the phylogeny of the Heteroptera.

The following study was carried on under the supervision of Professor Forbes, and I consider it an honor to be in a position to express my indebtedness to him for his constant aid and encouragement throughout the course of the work.

I am also greatly indebted to Dr. W. J. MacNeal, in whose laboratory I was very kindly permitted to do a large part of the work on the bacteriology of the subject, al though at that time the laboratory was so crowded that few men would have thought of admitting me. 

FUNCTION AND PHYLOGHIEIIC SIGIIFICAITCE

OF THE CAECA OF THE HETEROPTERA

The mid-intestine of the Heteroptera is typically divided into four rather clearly defined regions which, for convenience, may be termed the first, second, third and fourth stomach. All four can usually be made out, although in some of the more highly specialized groups certain of these aivisions, especially the two posterior ones, may be very greatly reduced.

At its anterior end the midgut is uniformly dilated, forming a capacious, thin walled, bag-like structure, capable of considerable distension. In the adult this anterior division is almost always e $\$ p t y$, although in the nymph it is often filled, and even considerably distended, with a greenish or brownish granular mass, ană, as might be expecteã, it is variable in size and shape in different individuals of the same species. At its posterior end this first stomach narrows suddenly and passes into the comparatively slender, tubular second stomach which usually is of uniform diameter throughout, and which empties into a second, oval or rounded, dilated portion. This third stomach, in turn, passes abruptly into the fourth and last division, which is the one that concerns us most, as it is on this section of the gut that the caecal appendages with their normal bacteria appear.

The first stomach is almost always distinct, while the second and thirả may occasionally grade into each other, in the more specialized forms, in such a way that the exact line sep- 

arating the two cannot be clearly made out. This fusion is brought about either by the excessive enlargement of the tubular second stomach or by the contraction of the third, or sometimes by both, and is met with only in those groups in which the caecal appendages are wholly wanting. In those groups in which the caecal appendages are regularly absent, the fourth stomach is uniformly reduced to an extremely short tubular portion, or it may occasionally be absent altogether, in which case the llalpighian tubes are inserted immediately below the third stomach.

In certain of the strictly predaceous groups, as in the Reduviidae, Phymatidae, and Acanthiidae, the midgut is very greatly reduced in complexity, there being no trace of the fourth and very little to indicate the second and third divisions, and even the first stomach may sometimes merge into the remainder of the midgut to form an irregular tube of large caliber extending from the oesophagus to the rectum, but without any clear-cut divisions. Even in cases such as this, however, there is usually a slight enlargement at the posterior end, just in front of the point of insertion of the lialpighian tubes; and this may represent the third stomach as it occurs in typical forms.

The fourth division of the midgut is never well developed ezcept in those of the Cimicoidea which are provided with caeca, and so far as is known these include only the Pentatomidae, Thyrecoridae, Pyrrhocoridae, Iygaeidae, and the Coreidae. In 

these families, whenever the caeca are present, the fourth stomach occupies a prominent place in the midgut in the form of a long, slender tube, and it is on the posterior end of this tube that the pouch-like caeca are borne. In these forms the tubular part of the fourth stomach is regularly somewhat dilated immeaiately below the third stomach, and this tendency is occasionally exaggerated to such an extent that in certain species, as in Blissus leucopterus, a bulb-like structure nay be formed at the anterior end of the tube nearly as large as the third stomach itself, but this dilation is not constant in size and does not represent one of the typical divisions of the midintestine.

The ileum in the Cimicoideae presents a characteristic modification which may well be mentioned here, for instead of continuing as a simple tube from the point of insertion of the lialpighian vessels to the rectum it forms a thin-walled, bladder-like reservoir, of various shapes, into which the four lialpighian tubes empty, eaç tube usually being inserted singly, about half way down on the side of this bladder-like ileum. The ileum opens by way of a narrow, valve-like constriction into the capacious, thin-wallea, muscular rectum, which may or may not be provided with a large anteriorly projecting cul-desac, depending on whether the ileum opens directly into its anterior end or further down on its side as it does in some of the Coreidae. rihe walls of the rectum are very elastic and its size varies greatly. When not gorged it may be no larger than 
the third stomach and still be smoothly rounded, while in the same species it is occasionally found so greatly distended that it occupies most of the abdominal cavity, although this conaition is decidedly exceptional.

As has already been stated, the caecal appendages of the Heteroptera are apparently confined strictly to certain families of the Cimicoideae; and while these organs at first appear to form a number of widely different types, they are found upon closer examination to fall regularly into two clearly defined groups ranging from very simple to highly complex forms. In one of these groups in which the Pyrrhocoridae, Thyrecoridae, Iygaeidae, and Coreidae may be included, the caeca are arranged in two rows extending along opposite sides of the tubular fourth stomach, in varying degrees of complexity, from an extremely simple type found in the Pyrrhocorinae (in which the caecal equipment consists merely of a double row of a half dozen or more comparatively minute outpocketings at the extreme posterior end of the tube) to the highly complex arrangement met with in the Largilnae and in many of the Coreidae and Lygaeidae (where the caeca may take the form of two rows of short closely packed units often numbering into the hundreds), or they may be arranged in definite groups of extremely long finger-like tubes, on opnosite sides of the intestine, much fewer in number than in the forms just mentioned, but compensating largely for the loss in numbers by a very marked gain in the diameter and length of the individual caeca. In all of these highly modified forms 

the typical arrangement is maintained. In the other group, including the Pentatomidae, with the exception of the Asopinae in which the caeca are absent, there are four rows of short, uniform, closely set, sac-like structures ranged along the tubular portion of the fourth stomach; and this arrangement is adhered to with remarkable uniformity in all the typical Pentatomidae so far examined.

Before discussing the various forms of caeca in detail, it might be well to consider the promable origin and course of development of these complex organs in the different divisions of the Cimicoidea.

Recognizing the Pentatomidae as the more primitive Heteroptera then, according to the view expressed by some authorities, Asopinae might be taken as representing the stock from which all the other Heteroptera developed. We find in examples of this sub-family, such as Podisus maculiventris (Plate IV, fig. 3), that the caeca are wholly absent, and that the fourth stomach consists merely of a short neck connecting the third stomach with the ileum. If we consider the Asopinae as representing a type which existed previous to the first appearance of caeca in the Heteroptera, then the Thyrecoridae should logically come next in the series, as it forms a perfect connecting link, so far as the caecal structures are concerned, between the typical Pentatomidae with their four rows of caeca and the Lygaeidae, Coreidae and Pyrrhocoridae with their two rows. In this family, as represented by lhyrecoris unicolor (Plate I, 
fig. 2), the caeca might well be regarded as showing a very primitive condition, since they apnear in a double row of very blunt evaginations from the wall of the gut which shows no indication of the distinct, narrow ducts so common in most of these insects, and which might readily be imagined as in process of formation directly from folds or wrinkles in the intestinal wall. No direct transition has as yet been seen between the double row of caeca of Thyrecoris and the quadruple arrangement in the typical Pentatomidae; but it can hardy be doubted that in some of the Thyrecoridae, or perhaps in the Cydninae, forms will be discovered in which the doubling of the rows of caeca is actually taking place. The specimens of Thyrecoris examined, and from which the drawing was made, were males; and as the caeca uniformly show a more complete development in the female than in the male, I should not be surprised to find at least indications of a third and fourth row when this sex is examined, although in the male the intestine does not show the slightest indication of this, even in sections. This arrangement apparently does very well in the Pentatomidae; but when the other families in which caeca occur are considered, a number of almost insurmountable difficulties are encountered.

It is easy to imagine how the complex types of caeca in the Coreidae, Lygaeidae, and Pyrrhocoridae could have originated from a common form like that of Thyrecoris, 

but the fact that in each of these families a number of species occur which are obviously not primitive, but in which the caeca are wholly wanting, is decidedly confusing when a progressive development the caeca is considered. Mr. C. A. Hart, of the State Laboratory of Natural History, has suggested that these caeca, instead of representing a continuous development in the existing heteroptera from simple to complex types, may be primitive ancestral organs which are really in process of elimination as the group advances in specialization; and that the confusing cases met with in the three families just mentioned should really be regarded as more highly specialized forms in which the caeca have entirely disappeared. This view seems to agree in essentials with the best grouping of the Heteroptera and Mr. Hart, who has very kindly compared the evidence presented by the structures with the principal systems of classification that have been proposed for these insects, finds that the relationship indicated by these structures agree remarkably well with the grouping of the Heteroptera as proposed by the great European Hemipterist, Stäl, although suggesting relationships decidedly at variance with those that have been assumed by certain by certain American workers.

The view that the complex types of caeca should be considered the more primitive, is also strongly supported by 

embryological evidence.

Upon dissecting the embryo of the pentatomid, Murgantia

histrionica, a day or more before time for hatching and shortly after the mid-gut had completely formed, the caecal region was found to be represented by a comparatively long, pink section of the intestine upon which the four rows of minute caeca were appearing, each caecum originating as an independent evagination of the wall of the embryonic intestine.

- A similar study of the embryonic gut of such Lygaeidae as Blissus leucopterus would be very desirable, in order to see if the typical grouping of the caeca of the Blissinae is not merely a specialization from from forms such as those in the Pachygronthinae.

An examination of the embryonic caeca of the Thyrecoridae would also be worth while, as it is here that we should expect the actual transition to take place from the four rowed form of the typical Pentatomidae to the forms with but two rows, if the caece in the heteroptera are really being reduced in complexity.

If this view is correct, and can hardly be questioned, then the Asopinae could not be considered the more primitive type of heteroptera, as has been suggested by kirkaldy, but would have to be considered a much more specialized group 
than the Pentatominae, in which the caeca reach their greatest development in such forms as Brochymena quadripustulata, where there may be as many as fourteen hundred caeca in the entire system. Just why the caeca should dropout so suddenly in the Asopinae is not clear, unless this is due to a specialization of the alimentary canal correlated with the strictly predaceous habits of the insects. In this connection it is of interest to note that the caeca are invariably absent in all the strictly predaceous Heteroptera. The scutellerinae, judging from their caecal equipment, are evidently close to the primitive Pentatominae. Of the Cydninae but a single male of Amnestus pusillus has been examined; and as the caeca were apparently absent in this specimen, this sub-family may be further removed than even the Thyrecoridae, although no generalization can be made from this one dissection.

In regard to the function of the caeca of these insects, it can only be said that no digestive function has been discovered, and that the food mass in process of digestion apparently never gets beyond the third stomach. This, together with the fact that these organs are located at the extreme lower limit of the digestive portion of the intestine and are apparently in process of elimination, would seem to show that they possess no important digestive 
function, although the great development of these structuresin forms like Brochymena would certainly suggest this. 

CONSTANCY OF THE CAECAL INFECTION IN HETEROPTERA

One of the first questions that came up in connection with the work was that of the constancy of the bacterial infection of the caeco-rihether these organs wore always infectod and whether the infecting organism was always the same. It had beon established by Professor Forbes that the infection in Blissus loucopterus was constant throughout the range of this insect in IIIinois, and all the Heteroptera in the neighbor hood of Urbana, in which the caoca were present, also showod the infection; but to make cortain that this relation was one of fundamental significance and that the infection was not merely a local phenomenon, peculiar to the Heteroptera of Ur bana, or perhaps of Illinois, it was plannod to seloct some common, widely distributed species and to examine specimens from as great a rango as possiblo.

It was necessary, of $\operatorname{cours} \theta$, that the species selected for a study of this kind should be widely distributed as well as common and easy to collect and, what was of ovon greater importance, that the caecal bacteria should be characteristio in form, to insure that the infoction was not due to different species of bactoria of similar form occurring in different parts of the range of the insect.

The Harlequin Cabbage bug, Murgantia histrionica, was finally chosen as the specios most nearly fulfilling thes $\theta$ conditions. It ranges from California across the southern half 

of the United States and thence to Now England; and it is usually a very comion and conspicuous form wherever cabbage is grown; but what made it especially suitable for this test was the large size and remarkable form of its oaecal bacteria. Instead of being minuto, short rods, as in Anasa tristis and Blissus leucopterus, the only two other species available for the test, those of Murgantia are very largo, contorted, spirochaete-like forms which could not possibly be mistaken for any of the other variotios of caocal bacteria.

To secure specimons, requests for living matorial wore sent to a number of station entomologists located in parts of the country from which lurgantia had beon reported. Living specimens were thus secured from ten states, extending in a continuous series along the southern and eastern part of the United States for a distance of betwoon two and three thousand miles, including California, New Mexico, Oklahoma, Arkansas, Mississippi, Alabama, Georgia, South Carolina, North Carolina, and lifaryland. The specimens of Hurgantia for this study were obtained through the kindness of the following entomologists -the locations given showing the place where the insects were collected:

T. B. Symons, Collogo Park, Maryland.

Franklin Sherman, Jr., Greenboro and Raloigh, North Carolina.

A. F. Conradi, Clems on College, South Carolina. 

H. P. Stuckey, Bxperiment, Goorgia.

W. E. Hinds, Auburn, Alabama.

R. H. Harnod, Agricultural Colloge, Mississippi.

Paul Hayhurst, Lanske, Arkansas.

C. E. Sanborn, Stillwator, Oklahoma.

Fabian Carcia, Agricultural Colloge, New Mexico.

C. T. Woodworth, Live Oak, California.

In addition to these localities, specimens of jurgantia were also examined from different parts of Illinois, especially from the southern part of the state, where they were collected by Kr. L. M. Smith of the State Entonologist's office; and two specimens wore also taken as far north as Urbana, IIIinois.

Upon a comparison of the contents of the caeca of specimens from these widely separated localities, it soon became ovident that the peculiar organism, first observed in the caeca of the tro specimens collected at Urbana, was a constant inhabitant of the caeca of Nurgantia, and that whether the individual examined was from California or Karyland this was invariably the highly charactoristic, contortod organism first observed in the Urbana speciriens.

While the caccal organisms from all these localitios are clearly of the same species, all having precisely the same typical form, there are oertain occasional differences in size that it may be well to mention. It was observed, for example, that in the insects from Georgia, as well as in occasional 

specimens from Illinois, the bacteria, although characteristic in shape, were often decidedly longer and stouter than those from most of the other localities; but this differenco in size was not constant in all the spocimens of lurgantia from these states, and it was doubtles $s$ due to some slight difference in the metabolism of the particular individuals examined.

Murgantia is the only species that I have studied in any numbers with this idea in mind, from outside Illinois; but hundreds of spocinens of other species have beon examined from different parts of this state, and all of these show, without exception, that in their morphology the type of caecal organism is absolutely constant for a given host species. 



\section{CULTIVATION OF THE CAECAI, BACTERIA}

In undertaking a study of the physiological relation existing between the Heteroptera and their caecal bacteria, it was very evident that the whole question hinged on the cultivation of these organisms, and that little or nothing could be expected from such a study until pure cultures were obtained. The fact that these were really normal bacteria and occurred in every individual possessing the caeca, in itself presented a very serious obstacle to the culture work, since this very fact apparently excluded all possibility of confirming, by direct infection experiments, any cultures that might be obtained from the caeca. An attempt was made, as has already been mentioned, to rear sterile individuals from the egg in aseptic cages, in order to secure material free from the caecal bacteria for these infection experiments; but since the bacteria were found to pass normally through the egg, these rearing experiments were unsuccessful; and this apparently left no alternative but to select for the culture work only those insects in which the bacteria were so characteristic in form that they could readily be recognized in mixed cultures. Since all possibility of checking the cultures by infection experiments had to be definitely abandoned, there was very little inducement, at least at first, to attempt the cultivation of these bacteria from the Coreidae or from such lygaeids as Blissus leucopterus, in all of which they are 

short, uniform rods with nothing morphologically to distinguish them from dozens of other saprophytic bacteria that might occur as contamination in the cultures. While these insects appeared wholly unsuited for preliminary culture tests, many of the Pentatomidae, as Peribalus limbolarius, Brochymena quadripustulata, and especially lifurgantia histrionica were apparently ideal for this purpose, as the bacteria which they harbor, instead of being the small, typical bacillus form of the Coreidae and the Iygaeidae, are very characteristic in appearance, varying from the extremely long, straight, rod-like forms of Peribalus through the short, uniformly bent organisms of Brochymena to the remarkably large, characteristically contorted form uniformly occurring in Ilurgantia.

For this apparently good reason, the culture work was, at first, concentrated especially on linrgantia histrionica and a few other pentatomids; for it was very clear that if the caecal bacteria from these insects would develop on artificial media at all, and still retain the characteristic form as they occur in the caeca, there would be no difficulty whatever in differentiating them from any possible contamination that might appear.

In the larger Heteroptera, as well as in those of moderate size, it was found that by careful dissection any division of the alimentary canal could be removed with practically no danger of outside contamination; the peculiar shape and structure of the abdomen in these insects being especially adapted 

to this operation.

For removing the caeca aseptically it was found, after a number of methods had been tested, that the following simple procedure was really the most satisfactory. The insect is first lightly chloroformed to prevent stmugling, the wings are clipped off near the base and the whole body moistened with alcohol to remove the film of air and allow the penetration of the bichloride solution which was usually used in the proportion of 1--500. The mercuric chloride solution is best applied with a bit of absorbent cotton held in a pair of old forceps. In this way the entire body of the insect can be thoroughly scrubbed with the disinfectant, so that any folds, such as those between the body segments, will certainly be moistened. After the bichloride solution has completely dried, which may be very well hastened by passing the insect back and forth before a Bunsen flame, the flat edges of the abojomen are clipped off, from near the posterior end up to the thorax, with a pair of fine scissors which have been previously flamed. The top of the abdomen immediately back of the thorax may be cut across with sterile scissors and the resulting. flap formed of the entire dorsal wall of the abdomen may then be lifted back with a pair of flamed forceps, leaving the abdominal viscera exposed. Usually in forms such as the larger Coreidae and Pentatomidae, the alimentary canal is considerably coiled in the posterior half of the abdominal cavity, and is covered above by a thin layer of fatty tissue which must be moved to one 

side before the caeca can be reached.

The caeca may be readily distinguished from the other divisions of the alimentary canal, as they are pure glistening white in the Coreidae or tinted yellow or pink in many of the Pentatomidae.

In making cultures from the caeca, the usual procedure was to open the abdomen with sterile instruments, in the manner just described, and after removing the dorsal fat body, to clip out a small section from near the middle of the caecal system, which was then quickly removed with flamed forcepts to a tube either of sterile salt solution or bouillon, the final cultures being made from this tube.

For reasons which have already been explained, the first serious attempt at cultivating the caecal bacteria was made with Murgantia histrionica; and unfortunately the work was confined for a long time to this species and a few other pentatomids, in an attempt to discover some means by which their peculiarly characteristic bacteria could be made to develop on artificial media.

When the work was first undertaken with Hurgantia, it was planned to remove a section of the caeca to a tube of sterile salt solution or bouilion as just described, crush it, and from this make plate cultures in the usual manner, it being fully expected that a number of doubtful forms of bacteria would be isolated as contamination from the ordinary transient intestinal flora assumed to be present in the insects. It was 
a decided surprise, however, when not only the typical caecal bacteria failed to appear in these plates, but no contaminating forms even developed. This was repeated with large series of the insects but the results were always the same, the cultures remaining sterile with a discouraging regularity. It was thought at first that perhaps the liberal amount of alcohol and bichloride solution used in disinfecting the outer surface of the insects might possibly have penetrated the tracheal system and that enough had been removed with the trachea adhering to the caeca to prevent all growth in the cultures, although this seemed hardly possible. Tests were made, however, in which only those parts of the insect which were actually to be cut were moistened with the disinfectant, the spiracles being avoided entirely, and the results were exactly the same, the cultures remaining uniformly sterile. It was later found also that without the use of any disinfecting solution the glands could be removed with no fear whatever of contamination from without provided the scissors with which the cutting was to be done were used hot enough to sear as the body wall*opened; the cuts being made as rapidly as possible to avoid the danger of heating the tissues too deeply.

While the apparent incapacity of the caecal bacteria from this insect to develop on orainary media was somewhat discouraging, at least one very important fact was brought out by it. Since no growth at all developed from the caeca on ordinary media, it was very clear that, contrary to what had been ex- 

pected, there would be no complication of contaminating organisms from the intestine which are so common in many other insects, since in lurgantia these forms seemed, for some very definite reason, to be wholly absent; and it followed that, if by any means conditions could be made suitable for the development of the caccal bacteria of this insect on artificial media, the difficulty of proving that the organism in culture was really the one sought and not some accidental contaminating form would be wholly avoided. With this as an encouragement, an excessive amount of time and effort was wasted in an attempt so to modify culture conditions that the normal caecal organism of this insect could be induced to grow on artificial media. Since, in reaction, the caeca appear faintly alkaline, the different media used were usually made neutral or slightly alkaline; and as the normal food of the insect is cabbage, this was largely used in the different media tested; but as all the results were uniformly negative, no minute discussion will be given here of the different modifications that were tried. Anaeroic cultures were also made with negative results, although at the time, this test seemed almost superfluous in view of the abundant tracheation of the caeca.

After the failure of these direct culture experiments, it was reasoned that upon the death of the insect the bacteria probably became gradually adapted to a saprophytic mode of life, and that by taking advantage of this they might still be forced to grow on artificial media. 

In testing this hypothesis, several series of from forty to fifty insects each were used. The insects were killed either with chloroform or by grasping the head for an instant with a pair of very hot forceps, the last method being the one most generally used and proving a very convenient way of killing the insect without breaking the body wall. The dead insects were then thoroughly sterilized by washing in a mercuric chloride solution after the removal of the wings, and after drying they were placed in small, tightly stoppered, sterile vials, to prevent drying of the internal structures, and kept for three or four days in a cold box at about $20^{\circ} \mathrm{C}$. At the end of this time the alimentary canal was usually intact and showed no invasion by foreign bacteria, while the caecal bacteria themselves showed no perceptible changes either in numbers or in the invasion of other regions. Bouillon tubes infoculated from the caeca of these dead bugs usually remained sterile, but growth appeared in two or three per cent. of the tubes, and it was thought at first that this growth might represent strains of the caecal organism which had been modified by their stay in the dead bugs as to develop on artificial media. When these cultures were examined under the microscope, however, they showed, not the long, irregularly bent organism from the caeca of Murgantia, but what appeared to be a pure culture of a very short, actively motile, flourescent bacillus, which grew vigorously on ordinary media. Although this organism was obtained in culture from ten or more of the dead insects and 

appeared to be the only one that developed, it was so different from anything that had been expected from the caeca that it was regarded as one of the common flourescent water bacteria that had probably been present in the anterior part of the alimentary canal and which, after the death of the insect, had invaded the caeca. The culture work on Murgantia was discontinued here, as it apparently promised nothing to warrant any further work.

In the meantime repeated attempts were also made to cultivate the caecal bacteria from a number of other pentatomids, including chiefly Peribalus limbolarius, Coenus delius, Brochymena quadripustulata, Euschistus variolarius anả lormidea Iugens, but the results, as with Murgantia, were uniformly negative, neither the caecal organism nor any contamination appearing in the cultures from any of these species, except in exceptional cases where the technique was clearly at fault.

Common forms such as the squash bug and the chinch bug had been purposely avoided in this work owing to the obvious impossibility of distinguishing between ordinary contaminating organisms and the caecal bacteria typical for these insects; but since the negative results from the work with Murgantia and the other pentatomids showed clearly that the caeca, in these insects at least, were wholly free from foreign bacteria, the possibility of using such insects as Anasa in culture work did not seem so hopeless as at first, especially if it was found that this statement applied also to thera. 
As a last resort it was decided to attempt the cultivation of the caecal bacteria from Anasa tristis, this species being selected because it is fairly large and is usually abundant and readily obtainable in winter as well as in summer.

In the preliminary work on this species, pieces of the caeca were removed and dropped at once into tubes of squash juice bouillon, the composition of which was the same as that of ordinary beef juice bouillon with the addition of a decoction from 150 grams of squash stems and leaves per liter.

In the squash bug the caecal bacillus is a very short, uniform rod, averageing 0.9 microns long by 0.7 microns wide. As they occur in the caeca these bacteria do not show the slightest indication of motility; and they are usually arranged in pairs, or they may, exceptionally, form short chains of from three to four or more individuals.

In undertaking the culture work with this insect I had very little hope of growing the caccal bacteria successfully, and really did not expect more than a repetition of the negative results secured with the Pentatomidae, but I nevertheless thought that even the relation shown there would be worth establishing in other Heteroptera.

The first culture experiments with Anasa tristis were undertaken with seven adults that had been kept in a warm room for nearly a month. Of the tubes infoculated from the caeca of these seven insects, every one developed growth; and in each case this appeared to be a pure culture of an organism 

morphologically very similar to the bacteria in the caeca; but as these insects had been feeding on partly decomposed squash a short time before the dissections were made, it was realized that the growth might very easily have been due to some foreign organism taken in by the insect from the decomposing squash. Nevertheless, the fact that the growth in all the tubes was apparently the same, was very encouraging in view of the uniform failure to secure any growth whatever from the Pentatomidae.

To ascertain whether or not this growth was merely a contamination from the squash, or whether the caecal organism could still develop saprophytically, as the culture suggested, a series of fifty specimens of Anasa were taken, fed on perfectly fresh squash for two weeks and then kept for a full week without food, in order to give the caecal bacteria sufficient time to destroy any contaminating organisms that might have been swallowed while feeding.

Cultures vere made from this series and, to my surprise, growth developed in all fifty of the tubes and appeared in each case to be a pure culture of a short, motile organism identical in size and form with the bacteria in the caeca of this insect, and so far as could be determined these were the same as the organism that had appeared in the cultures from the first seven insects tested.

This series of experiments appeared to show very conclusively that we had at last succeeded in growing the caecal bac- 
teria in pure culture, provided of course that foreign bacteria were excluded as completely from the alimentary canal of Anasa as they had been shown to be in the Pentatomidae. Sub-cultures were not started from these tubes for seven or eight days and upon examining them again at the end of this time, a number were found to contain organisms so different from the caecal bacteria that there was apparently no escape from the conclusion that the cultures had become in some way contaminated. Then examined upon the first appearance of growth, nothing was found but the short uniform bacillus, which was as much like the bacteria direct from the caeca as coulà be imagined; but at a later examination two apparently distinct contaminating forms were discovered. One of these apparent invaders was a fairly uniform rod-shaped bacillus 4 microns long by 1.5 micron wide, so much larger and longer than the typical caecal organism that the two could be distinguished at a glance. The other was a perfectly spherical form, 0.6--0.8 of a micron in diameter, which occurred commonly in extremely long chains of a hundred or more individuals.

Contamination from some source had apparently taken place in a number of tubes, and it was therefore decided to discard the whole series rather than attempt to make a detailed study of the different forms that might be isolated from the cultures in an attempt to connect some one of these vith the spe- 

cies from the glands--an undertaking evidently little short of hopeless. Another cause of uncertainty here was the fact that the caecal bacteria from the Pentatomidae would not develop on ordinary media; and as there was no reason whatever for assuming that the forms from the Coreidae would behave any differently, there was clearly a possibility that the growth that had appeared in all the tubes was really, contamination and that the true caecal bacillus was not represented here at all. If the property of totally excluding all other bacteria from the alimentary canal did not hold for the caecal bacteria of the Coreidae, as it very clearly did for those of the Pentatomidae, then there was certainly very little encouragement to continue culture work with these insects, for, although strains of bacteria might be isolated that would agree perfectly with the caecal bacteria in their morphological characters, this would establish very little, as there is nothing about the bacteria from the Coreidae to distinguish them in this way from many common saprophytic forms that might readily gain access to the intestine of these insects.

As the first two sets of culture tests were made from bugs that had been kept in a warm room and had been feeding continually up to a week of the time before the dissections were made, it seemed possible that the antagonism of the coreid bacteria to invading forms was not so absolute as in the Pentatomidae, and that, if hibernating insects were used which had had no opportunity to feed for a considerable period, the normal bac- 

teria might in this time have succeeded in effectually killing off the foreign species. It was accordingly decided to attempt the cultivation of the squash bug bacillus once more, hibernating insects being used this time in the hope that as a result of long fasting their normal bacteria might have eliminated the transient forms.

For these tests, the insects were taken after the middle of December from their winter quarters. They could not have fed for at least a month; and they were dissected at once. Thirty-five specimens of Anasa tristis were collected for this work and every precaution was taken in the dissections and inhoculations to guard against contamination from without. The insects were sterilized before dissection with a thoroughness which would not have been permissible with Murgantia; but, notwithstanding this, cultures were obtained from these insects as regularly as they had failed where Murgantiawas used, all thirty-five of the tubes iffnoculated developing an abundant growth.

These cultures were incubated at room temperature and were watched closely for the appearance of any contamination. Growth was found to appear rather tardily, developing in from two to four days and at first, as in the two previous series of experiments, consisting of an apparently pure culture of a short, motile organism which could not be distinguished morphologically from the caecal bacteria as taken direct from the insect. In a few days after the first appearance of growth, however, forms 

were observed in many of the tubes which were clearly not of this type. In about a week the two abnormal forms which had appeared in the preceding experiment were observed in a number of these tubes; and, in addition to these, a third type was also discovered which appeared in several of the tubes as a very large, oval, yeast-like organism often over five microns long by four microns wide.

As all contamination from without had been excluded beyond question, all of these unusual forms must certainly have come from the caeca; and as nothing resembling any of them had ever been observed in these organs by direct examination, their appearance in the cultures was very difficult to explain. Upon close examination it was seen that these contaminating organisms were not strictly constant in form, although it did not seem possible at first that these strikingly different organisms could be involution forms of the bacillus that first appeared in cultures from the caeca. The yeast-like bodies were usually free, with one or more small typical buds at the ends; but occasionally one or more of these large bodies could be seen in the long chains of small coccus-like forms; and the large bacillus was not always a typical rod, but very often tapered at the ends very decidedly, and even merged into bodies that resembled the yeast-like forms. Since it seemed possible that some of the contaminating organisms were merely involution forms, and not independent organisms, as had been assumed at first, it seemed worth while to make a thorough study 

of the different forms occurring in the cultures to determine how much normal contamination there really was in the alimentary canals of these insects. Plate cultures vere accordingly made from some of the tubes that appeared most highly contaminated, and these were searched very carefully for different kinds of colonies; but so far as could be determined by direct examination, the colonies were invariably all alike.

Cultures were made from large numbers of these colonies in an attempt to isolate the different contaminating organisms that had appeared in the original bouillon tubes. All the subcultures from the plates invariably developed into the short form resembling the caecal bacillus; but when sub-cultures were made from these into bouillon, all the abnormal forms regularly appeared, as they had in the cultures direct from the caeca. Since each colony in the plates contained only descendents of a single bacterial cell, it became very evident that the apparent contamination from the caeca of the squash bug was nothing more than an extreme case of the production of involution forms, and that but a single organism had ever really developed in cultures from the caeca of these insects. This established conclusively the fact that we had but one organism to consider in the culture from the caeca of Anasa tristis although it did not show beyond question that this one organism was really the true caecal bacillus. In view of the result: from the culture experiments with lifurgantia, however, it certainly seemed probable that this was the caecal bacillus. 

One fact which made this view rather uncertain for a time was that in 1895 a generally distributed disease of the squash bug was discovered by Duggar in the neighborhood of Urbana. This disease appeared to be fairly common, and was described as affecting principally the fat boojy and the perivisceral tissues generally. There was a distinct possibility that a chronic form of this disease might be present among the apparently healthy bugs that had been used in the culture tests just described, and that the growth in these cultures was really due to this organism from the fat body contaminating the caeca as they were removed from the insect for innoculation. No more insects were available for testing this theory, but the following season several large series of culture tests were carried out with this point in view, two tubes being innoculated from each insect in the following manner: Upon opening the abdomen a large lobe of the fat body adjacent to the caeca was removed, before the alimentary canal was broken, and placed in one of two tubes of bouilion. A section of the caecal system was then removed and put into the check tube. Without discussion of detail, it is enough to say that as a result of several hundred such tests growth was obtained from the caeca in every case, while the tube innoculated from the fat body invariably remained sterile.

In order to ascertain the distribution of the caecal bacteria throughout the alimentary canal, cultures were made from different sections of the mid gut, including the first stomach, 

third stomach and the caecal region. From a large number of such tests it resulted that while growth invariably appeared in the tubes from the caeca, and usually also from the third stomach, only from ten to twenty per cent. of the innoculation. from the first stomach showed any growth, all the others remaining sterile.

Cultures were repeatedly made from the eggs of Anasa tristis; and upon comparison, it was found that the organism from this source vas certainly the same as that isolated from the caeca, and it was also determined that this was the only organism that ever appeared in cultures from the eggs of this insect.

It was expected, in the beginning, that the bacteria from the caeca of the Heteroptera, if they developed at all on artificial media, would prove to be a number of very different forms, perhaps occurring only in their respective insect hosts, and when it was found that the organism isolated from the caeca of Anasa belonged to so common a groun as the non-liquefying: flourescent bacteria, it was feared that, after all, the form isolated from this insect might have been merely the result of a contamination of the alimentary canal by some of the ever present species of this group; although the fact that this same organism was isolated regularly from the egg seemed very conclusive.

In order to show bejond question whether or not the bacteria so regularly isolated from the squash bug were really the 
same as those normally present in the caeca, it was planned to check the cultures which had been obtained from the insects against the bacteria direct from the caeca by means of the agglutination test. Young rats were chosen as best suited for this work, as they are much more hardy than young guinea pigs of the same weight. The animals selected weighed only from fifty to seventy-five grams, as it was feared that sufficient material for the immunization might not be available in case large animals, such as full grown guinea pigs, were used. It was planned at first to immunize the animals to cultures of the bacillus isolated from the caeca, and to test such sera against emulsions of the bacteria direct from these organs; but owing to the fact that bacteria freshly isolated from tissues do not usually react so readily to the agglutination test, the process was finally reversed and the animals were immunized with material direct from the caeca.

For this purpose the caeca were removed from hibernating insects and crushed very thoroughly by rolling between sterile slides. The bacteria thus liberated were then washed off the slides and collected in sterile vials which were at once immersed in a water-bath and kept at $54^{\circ} \mathrm{C}$. for thirty minutes to kill the organisms, it having been found that this temperature was sufficient for the purpose.

Naterial prepared in this way was injected intra-peritoneally, each animal receiving five graảed doses at intervals of 

a week or ten days. the doses varying from the caeca substance of ten bugs for the first injection to that from thirty insects for the last.

The immunized animals were killed about ten days after the last injection, the blood was draw aseptically from the heart, and the serum storea in capillaries having a capacity of two or three drops each. Since the normal serum of many animals is known to agglutinate certain strains of bacteria in low àilution, I did not know what to expect in a case like this from the serum of normal rats, anả to guard against any possible error from this source, a normal rat was bled whenever an immunized animal was killed and the sera from the two were checked against one another in every test made.

A large series of cultures from the caeca of Anasa tristis were tested out against such immune sera, and from the very first of these tests it was evident that the organism in culture was undoubtedly the identical form in the caeca, for they were agglutinated readily by the immune serum of the caecal bacteria in dilutions as high as 1--500. No dilutions higher than this were tried, but from the readiness with which clumping was produced in this concentration, we may infer that the reactions would certainly have been reliable in dilutions twice as great.

In this work the macroscopic method was relied upon almost entirely, the dilutions being made in small, 6 or $7 \mathrm{~mm}$., test tubes. It was found that while serum from the immunized rat 

would regularly produce complete clumping in high dilutions in three or four hours, when incubated at $35^{\circ} \mathrm{C}$, the normal serum in these same dilutions gave no trace of the reaction. It shoved no more flocculation than regularly took place in the untreated checks, although there does appear to be a slight reaction in dilutions as high as 1--20 where normal rat serum is used.

From a careful study of the bacteria as they occur in the caeca of the different Ieteroptera, supplemented by the results of this culture work, it seems highly probable that many, and perhaps all, of the different and highly characteristic forms observed in the caeca of so many of these insects are really abnormal involution forms of an organism presumably something like the caecal bacteria of Anasa tristis. This cannot be certainly determined, however, until at least a few of these peculiarly shaped organisms have been cultivated beyond question. It will be remembered that during the culture work with the caecal bacteria of lifurgantia histrionica, growth was secured from a small percent. of the insects that had been dead for some time. The organism isolated was a short, motile form, very similar in shape and size to the bacteria from the caeca of Anasa tristis, but as there appearea, at the time, no way of determining whether these really represented the true caecal organism, or were merely accidental invaders which had appeared after the death of the insect, the cultures were discarded. Evidently the only perfectly reliable method available in 

a case such as that doscribed for Murgantia, is the agglutination test as applied to the cultures from Anasa tristis--immunization with the bacteria of the particular insect studied, direct from the caeca, and testing the resulting serum against any doubtful cultures obtained from these organs. 

ORIGIIN OF THE CAECAJ INHECTION IN THE HETEROPTERA

At an early stage in the work it became evident that one of the first things to be determined was the exact time and manner in which the infection with the caecal bacteria normally takes place. Assuming that the normal bacteria would develop readily in artificial cultures, the next essential step would be to differentiate between this organism and any of the common saprophytic or parasitic forms that are so frequently met with in the alimentary canal of most insects, and which would naturally be expected to appear also in cultures from the caeca. Until the identity of the normal species in culture could be established beyond question, it would clearly be useless to undertake any time-consuming study of the physiology of any of the organisms that might be isolated in an attempt to correlate this with the digestive processes in the insect; and at the commencement of the work it appeared that the only possibility of certainly differentiating between the normal bacteria and the contaminating forms that might appear, was in some way to secure insects free from the infection, and then by direct feeding experiments to determine which were really the "caecal" bacteria.

The normal bacteria are present, not only in the caeca, but also in considerable numbers free in the alimentary canal of the host and, as might be expected, they also occur in the browish, liquid excrement of the insect. It is easy to im- 

agine from this how the surroundings might be very highly contaminated with this organism, especially in the case of many of the common gregarious, phytophagus Heteroptera, such as the chinch-bug, the squash-bug, or Murgantia. It is a very common habit with these insects, as I have frequently observed, especially when in the immature condition, to sample with their beaks any àrop of liquid that they may find; such as drops of dew, drops of sap exuding from wounds in the host plant, or even the liquid excrement from other individuals.

From these facts, and since the bacteria appeared to be limited to the alimentary canal of the host, it was assumed that the infection probably occurred by way of the mouth and that the alimentary canal was doubtless invaded at some time during the early nymphal life of the insect.

Proceeding on this assumption, it was planned to rear the insects from the egg in sterile cages in order to have material for use in infection experiments with the different organisms that might be isolated from the caeca. Anasa tristis was selected at first for this rearing work, since the eggs of this species are very easily obtained in quantities at any time during the summer, and also because they are perfectly smooth and readily sterilized. As it was planned at first, the rearing of these sterile bugs should have been a comparatively easy matter. Since it was found that this insect is able to live and develop fully as well on the squash itself as upon the sap of the vine and leaves, the only essential equipment for a 

breeding cage would have been very simple indeed. The breeding cage, as I had intended to arrange it, was to have been merely a rather wide necked Ehrlenmeyer flask of something like 500 c.c. capacity, plugged with cotton and sterilized. Small pieces of squash, removed aseptically, were then to be introduced into the flasi, together with the sterilized eggs of the squash bug.

As a preliminary to this breeding work, experiments were carried out to determine whether aseptic material could be readily secured from the squash, and especially whether the eggs of the squash bug could be sterilized effectively without interfering with the subsequent development of the embryo. It was found that with a little care, pieces could be removed from a squash without any risk of contamination; and it was also found that the development of the eggs of the squash bug was in no way hindered by a very thorough treatment with mercuric chloride. When such eggs were placed in bouillon as a check on the thoroughness of the disinfection, they would remain apparently sterile for a period of three days or more and then, at about the time the experiment should have been considered a success, an abundant growth would suddenly appear which apnarently consisted of a number of different contaminating organisms. This test was repeated a number of times, with certain variations in the method of aisinfection. It was thought at first that perhaps the film of air surrounding the egg prevented the aqueous bichloride solution from doing effective work, 
and the eggs were accordingly first maistened with alcohol to remove the film of air; but no matter how thorough the disinfection was made, the confusing growth almost alvays appeared. Since there could be no question but that the surface of the eggs had been completely sterilized, there remained nothing but to conclude that the contaminating organism or organisms were within the egg itself.

As is well known, the eggs of birds may sometimes contain bacteria while still in the oviduct, and before the shell has been laid down, so that when the shell is formed they are included within it. There is no reason why the egg of an insect should not become contaminated in much the same way, and it was thought at first that this must be the case with the eggs of the squash bug. This species was accordingly abandoned, since it was clearly out of the question to rear sterile individuals of it. A little later in the season a few eggs were secured from specimens of lifurgantia histrionica that had been received from Dr. \#. E. Hinds, of Auburn, Alabama; and it vas decided, as a last resort, to test these to see if they were also contaminated. These eggs were given exactly the same treatment as had been given those of the squash bug; but instead of developing the contamination that appeared so constantly in the squash bug eggs, they invariably remained sterile and showed no growth whatever, even when crushed immediately upon being placed in the bouilion.

Before undertaking the rearing work on lifurgantia that was 

logically opened up by these negative results, it was decided to determine just how long after hatching the infection really occurs under normal condition. A fairly complete series of the immature stages of this insect was available at the time, and starting with a half grown nymph, the caeca of successively younger inàiviảuals were examined until a stage only a few hours old was reached without finding a single specimen free from the infection. The next step was to examine a nymp immediately after hatching and before there was any possibility of its having fed; and as the caeca of this specimen also proved to be infected, it became evident that the caecal organism itself must be transmittea directly through the egg. In order to establish this point beyond question, embryos of lifurgantia in different stages of development were examined, and it was found that in an embryo taken as early as fortyeight hours before the time for hatching, the organism which had been founa uniformly in all the post-embryonic stages of the insect, also appeared in the embryo. The bacteria appear in that section of the gut which is due to develop into the caecal apparatus of the adult insect and which, oving to its pink color, can readily be distinguished from the other embryonic divisions of the alimentary canal.

While the bacteria from the embryo of linurgantia, twentyfour to forty-eight hours before hatching, are comparatively very few in numbers, they nevertheless show the same characteristic, spiral forms that are met with in the adult, although 

those from the embryo are usually much shorter and decidedly more difficult to stain. A considerable number of embryos of this insect were examined in this way and, without exception, the caecal region in all was infected with the same peculiar contorted organism.

These observations on Murgantia naturally suggested that the apparent contamination from the eggs of the squash bug migint also have been aue to the caecal bacillus of this insect carrying through the egg in a similar manner; although the fact that no growth was secured from the egos of flurgantia, in which the caecal bacteria had been demonstrated microscopically, vas rather unfavorable to this view. This fact also seemed to indicate that perhaps the caecal organism was so closely adjusted to conditions in the body of the host insect that it would not develop readily on artificial media.

At this time no more eggs of the squash bug were available, and the cultures from them had all been discarded as of no significance; but the following season, when the matter was again investigated in the light of these new facts, it was found that the cultures that developed so regularly from the eggs of this insect were identical with those that were also secured from the caeca, and that instead of containing a number of contaminating organisms, the growth really consisted of a pure culture of the caecal bacillus. The reason for believing, at first, that the cultures from the eggs represented more than one organism and the fact that no growth vas secured from the 



\section{(46)}

eggs of Ifurgantia are discussed in connection with the regular culture work; and it is enough to say here that when ordinary care was taken in the disinfection of the eggs of Anasa tristis, the resulting growth was invariably a pure culture of the caecal bacillus.

It was also established for a number of other species, including the lygaeid, Blissus leucoptemas, that the bacteria are present in the caeca of the nymph immediately after hatching, and consequently, at a time when all outside contamination could be excluded; but it was considered a piece of unnecessary routine to attempt to carry the examination back into the embryo of these forms as had been done in the case of Anasa tristis and Wrgantia histronica.

The exact manner in which the caecal association developed in these insects can, of course, only be surmised. It is possible that the present nornal bacteria were formerly pathogenic for the host, and that the caeca as they now'exist, originally developed from true pathological stmetures formed as a result of the invasion of the tissues by these organisms; or the bacteria may originally have been merely saprophytic forms, peculiar to this section of the alimentary canal, which gradually became adjusted to an existence in the caeca.

One factor that might be regarded as supporting the first view is the fact that the bacteria are, to a certain extent, intra-cellular; and it is easy to imagine how these organisms, originally attacking certain of the epithelial cells of the gut, 

might have stimulated the formation of pathological caeca, which, being incidentally of some use to the host, were preserved and even greatly elaborated in structure. There is somewhat better reason for believing, however, that the caeca were originally independent organs which finally came to be occupied by the normal bacteria, and this subject will be taken up under the discussion of the caeca themselves.

That the infection is regularly transmitted through the egg from generation to generation is very evident from the above facts; but this does not necessarily mean that the organism is so closely bound up with the host as to exclude the possibility or even the importance of infection from without. One hardly believes that reinfection by way of the mouth, whether an important factor in the association or not, is not constantly taking place, at least from the excrement of other individuals if not also from some unaiscovered form of the organism that may exist nornally as a free saprophyte.

As is well known, certain pathogenic blood parasites, as the spirochaets, are regularly transmitted through the egg from one generation to succeding generations of the intermediate host, which is a tick in the case of Snirochaeta duttoni. It has been established, in this particular case, not only that the mother that swallows the infected blood may transmit the parasites to her young, but that their descendants, although allowed to feed only on clean animals during their entire life time, may also pass this second-hand infection on to their 
nust apparerity taise riace. It may be that onditions in the arthropod host are unfavorakle in some way to the spirochaets, 
young. Transmission may not stop even here, as it has been clearly established that it may continue in this way for at least three generations of ticks.

Just why this process should not go on indefinitely, when once the infection is acquired by the tick, is not clear; but evidently it does not, as only a comparatively small per cent. of the individuals of Ornithodorus moubata are able to transmit the disease to man.

In order for the association to continue, repeated infections with the blood-inhabiting forms of the spirochaets,

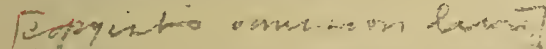

and that they gradually degenerate in passing through a number of generations of the host, so that for a continuance of the association a periodical reinfection with a more vigorous strain from some outside source is required. While the occurrence of a similar relation in the Heteroptera is by no means certain, there are a number of facts pointed to both by direct observation and by analogy, that would seem to favor this view rather than the theory that the bacteria are confined strictly to their insect hosts and are transmitted indefinitely from generation to generation through the egg.

One reason for the first view is that in certain of these insects, as in lurgantia and in many other pentatomids, the bacteria really appear to be existing under marked difficulties of some sort, as indicated by the proportion of involution forms and the constancy with which they appear in the caeca of these insects, and also by the fact that the majority, at least, 
are apparently unable to develop any longer on artificial media.

Another case that may throw some light of analogy on this question is that of the well known symbiotic relation between certain green turbellarians and their associated algae. Numerous attempts have been made to cultivate these algae on artificial media, but uniformly without success. Ihis was sometimes explained on the theory that these two organisms had been associated in this relation for so long that the alga had completely lost its ability to develop in the free state, and was now totally dependent on the animal as is often the case in many of the more highly specialized parasites. This is certainly a very reasonable viev but it has recently been discovered that the zoochlorellae, although exerting a profound influence on the metabolism of the host, do not represent the typical organism any more than the Leptus irritans stage could be taken as representing the true life cycle of the particular species of Trombidium to which it belongs. The zoochlorellae, like Ieptus irritans, really represent an abnormal departure from the regular development of the species. The form to which these symbiotic algae belong is really a typical, free living, flagellated organism, which is normally free during its entire, regular life cycle, the zoochlorella stage representing merely those individuals which chance to be swallowed by the worm. The free living stage of this organism will grow vigorously on artificial media and infection is found to take place readily 

from pure cultures, but in the case of the organism direct from the tissues of the host worm it has been found not only that they will not develop on artificial media, but that they have been so modified by their short existence in the body of the host, that they are not even able to set up the infection in clean worms although they may be swallowed in quantities. In certain coelenterates the relation of the alga to its host animal appears to be better established than in the planarians, as in Millepora; at least they are found in the egg and appear to be transmitted through the egg for at least one generation; although there is a possibility that the inclusion of these organisms in the egg is a mere accident and that the chief source of infection is the free living stage of the alga which is continually being swallowed by the animal.

The only other bacterial infection in insects directly comparable with that in the Heteroptera is one whose relations have been worked out by Petri for the little olive fly, Dacus oleae--a subject which will be discussed in detail in another place. In this insect the bacteria, which are also intestinal forms, are present in the larva as well as in the adult and, according to Petri, there is a complicated modification of the ovipositor which functions as a secondary reservoir for the intestinal bacillus. Petri at first very naturally reasoned that since these bacteria were present in larvae that had hatched from eggs laid by sterile flies in sterile olives, the organism must be transmitted through the egg; but in his lat- 
er work he concludes that this is not the case, and he finally decided that infection normally took place in the following manner:- When the fly deposits its egg in the fruit of the olive, a quantity of the bacteria from the special structures in the base of the ovipositor are also introduced and infection only takes plaoe when the young larva, upon hatching, swallows some of the surrounding bacteria. Petri also isolated a chromogenic organism from the soil of olive orcharảs and from various parts of the olive tree which he regards as identical with that from the intestine of Dacus, and he seems to think that the insect originally developed its infection from this free, saprophytic form.

The organism isolated so uniformly from the eggs and caeca of Anasa tristis clearly belongs in the large group of flourescent bacteria that are so common in water and in soil generally. A number of strains of these saprophytic flourescent organisms have been isolated and studied from the soil about squash vines and from the squashes themselves; and they clearly belong in the same groun with the caecal bacillus of Anasa tristis, although certainly none of them are identical with it. 

FUINCTIONAI, RELATION OF CAECAI BACTERIA TO THE HOST INSECT

In considering the possible relation of the caecal bacteria to the life processes of the insect, a digestive function is at once suggested on account of the great number and apparent Iimitation of these organisms to the digestive tract of the host. One point, however, that was rather puzzling and decidedly difficult to understand on this basis was the peculiar localization of the infection in relation to the digestive portion of the gut.

Digestive caeca are very common in other groups of insects, occurring notably in the Orthoptera, Coleoptera, and Diptera, as well as in several other orders, but with one or two isolated exceptions these organs are invariably located at the anterior end of the midgut, often serving as reservoirs for the food in which certain definite digestive processes take place. In the Heteroptera, however, the caeca, and consequently the intestinal bacteria, are located at the very posterior end of the midgut, and these organs appear to have lost their direct digestive function, since neither they nor the fourth stomach itself ever appear to contain any food, the last stages of digestion apparently taking place in the third stomach, which is usually found to contain some material in process of digestion. Just how to correlate the singular localization of the intestinal bacteria in these insects with any digestive process was by no means clear, and this remained 
more or less of a mystery until explained by culture experiments.

It is a well known fact that most insects, whether feeding on solid or liquid food, support a great variety of saprophytic and parasitic bacteria and protozoa in the alimentary canal. This relation is especially marked in those insects feeding normally on solid materials which may be more or less contaminated in the beginning, but it also applies to sucking insects which feed normally on sterile liquids, although such insects are usually less heavily infected. llosquitoes and other blood sucking insects are excellent examples of this, for while they feed on the normally sterile blood of vertebrates they usually contain a great variety of bacteria and flagellate parasites in the stomach and intestine generally which clearly have no relation to the vertebrate from which the food was secured.

Early in the work a peculiar infection was observed in Peribalus limbolaris, a pentatomid in which the caeca are well developed. In the specimens of this species, collected from certain localities, fully ten per cent. of the individuals showed an extremely heavy infection of the large sac-like reservoirs of the salivary glands with a flagellate of the Herpetomonas group. This organism was apparently going through a normal developmental cycle in these organs, as all stages could be readily observed, ranging from minute, roundeà or pear-shaped, non-motile bodies, with a distinct nucleus and 

blepharoplast, but with no flagellum, to the long, slender, typical Herpetomonas stage. lihltiplication rosettes were also abundant, showing that the organism had evidently fully established itself in these organs. Infection with organisms very similar to the species found in Peribalus have been observed and described in connection with a very large number of different insects, including especially many Diptera and predaceous Heteroptera, but so far as I have been able to discover, these infections have been confined strictly to the stomach and intestine and are never known to occur in the salivary glands.

In working up the development of the Herpetomonas from Peribalus, the alimentary canal was searched very carefully in a large number of individuals, as it was thought that the organism observed in the salivary glands probably represented the final stage in the life history of some intestinal form; but although a very thorough search was made, not the slightest indication was found of an invasion of the midintestine by this parasite, although the salivary glands often appeared almost completely filled vith them.

Some time later, upon examining specimens of Podisus maculiventris, an insect of the same family, but in which the caeca are vholly wanting, a similar infection was observed. This time, however, the alimentary canal was the seat of the infection; and although a very careful examination was made of the salivary glands in specimens showing a very heavy in- 

testinal infection, these organs were found to be invariably free from any infection with the flagellate. In Prodisus the infection appears to be remarkably common, fully fifty per cent. of the specimens from some localities containing this parasite. The third stomach seems to be the place of greatest multiplication of the flagellates in this insect, and not only the Herpetomonas but also various forms of foreign bacteria were observed in this region. Ihis is in marked contrast to the condition found in the midgut of those forms which are provided with caeca; for of the hundreds of typical pentatomids examined, flagellates were found in the alimentary canal of but two specimens of Coenus delius, which were apparently on the point of dying when dissected, and in these the parasites were confined chiefly to the first stomach instead of reaching their greatest development in the third stomach as in Podisus.

For a long time after the singular infection of the salivary glands in Peribalus had been observed, no satisfactory explanation could be offered for the strict localization of the typical intestinal flagellates in these organs. It was not realized at first that there might be some possible connection between this phenomenon and the bacteria normally infecting the caeca of the insect, but later when this case was compared with similar infections in such forms as Podisus, in which the caeca were wholly wanting, it seemed that the caecal bacteria must in some way be responsible, and this view was 

later confirmed by direct culture experiments.

Vie may assume that these Herpetomonas parasites, upon being continually introduced into the alimentary canal of Peribalus, and being unable to develop in the midgut in the presence of the antagonistic caecal bacteria, gradually become adapted to a life in the bag-like salivary reservoirs instead of being excluded entirely as was apparently the case in most other Heteroptera in which the caeca are present.

As a result of the apparent failure in the culture work with lifurgantia and the other Pentatomidae followed by the successful cultivation of the caecal bacteria from Anasa tristis, it became evident that at least one perfectly clear-cut function possessed by these organisms, whether of profound importance to the host insect or not, was the antagonism which they certainly exhibit towards other bacteria and protozoan parasites which would normally be expected to occur in the intestine of such insects.

In the culture work on the Pentatomidae it was found that the entire caecal system of one of these insects could be removed and aropped directly into a tube of bouillon or other media, where it would remain for a month or more without a trace of growth developing. This was not an occasional occurrence, but was invariably the result secured where the Pentatomidae were used and demonstrated conclusively that the caecal bacteria are not only antagonistic to the ordinary saprophytic and parasitic bacteria, but prevent their development entirely, 

and apparently kill them when they invade the alimentary canal of these insects.

In the somewhat similar association described by Petri for the larva of Dacus oleae the bacillus concerned was found to secrete an active lipolytic enzyme which presumably assisted the insect in digesting its oily food, but unfortunately Petri apparently did not consider the possible antagonism of these caecal bacteria of the fly toward the forms which commonly invade the alimentary canal of such insects; and it is consequently imposible to say whether the caecal bacteria of the little fly resemble those of the Heteroptera in this regard or not.

In regard to a digestive function for the caecal bacteria of the Heteroptera, it can only be said that in cultures these bacteria apparently secrete no enzyme that could be of any evident assistance in the digestive processes of the insect, and this agrees perfectly with the peculiar localization of these organisms at the extreme posterior end of the digestive portion of the gut, which in itself would render the probability of their assuming an important part in the digestion of the insect extremely small, even though they had been found to secrete important digestive enzymes.

The deficiency in enzyme production shown by these organisms will be taken up in connection with the culture work, and vill not be discussed here; although it might be mentioned that when the caeca, together with a considerable section of 

the intestine was removed, as in the Pentatomidae, and dropned into a tube of bouilion, the tissues would remain white and apparently normal in every way for several weeks, or longer, although crammed full of the caecal bacteria. This would show, at least, that the caecal bacteria do not secrete a proteoIytic enzyme. The same peculiarity was also observed in cultures from Anasa tristis, the tissues remaining unchanged even after the cultures had been growing vigourously for a week or more.

In the case of certain of the intestinal bacteria of the higher vertebrates, there is a well known association existing between these organisms and the host that is remarkably similar in many ways to the one just described for the Heteroptera, although as might be expected, it is complicated, in this case, by a vast number of factors that do not have to be taken into consideration in a treatment of this relation in the much more simple insects.

Practically all the higher animals harbor certain varieties of intestinal bacteria which have become so intimately associated with the host that they are generally referred to as the "normal" intestinal bacteria; and there has been a tremendous amount of work done in the attempt to determine the exact functional importance of these organisms from the standpoint of the host. As might be expected, by far the greater part of this work deals directly with those forms peculiar to man and the higher vertebrates, but as many of the principles 

which have been worked out for the association in these animals throw a great deal of light on conditions as they exist in the Heteroptera, the following very brief summary of the pertinent work that has been done on this subject should not be out of place. 


\section{IMPORTANCE OF THE "NORMAL" INTESTINAL}

BACTERIA TO THE HOST

- The fact that certain specific bacteria occur with remarkable regularity in the complex intestinal florafof the higher animals was early recognized by bacteriologists, and this knowledge naturally led up to an extended discussion concerning the true relation of these "normal" intestinal bacteria to the animal harboring them.

As early as 1885 Duclaux, by a simple experiment established the fact that the higher plants are unable, in themselves, to utilize the more complex forms of nitrogen and that they are absolutely dependent upon the action of certain classes of bacteria normally present in the soil for their supply of this essential element of plant food.

In the same year, in commenting upon the results secured by Duclanx for plants, Pasteur gives with characteristic directness his views concerning the relation of intestinal bacteria to the assimilation of higher animals. In the following well known quotation he says:

"Souvent, dans nos causeries du laboratoire, depuis bien des années, j'ai parlé aux jeunes avants qui m'entouraient, de l'intérêt qu'il y aurait à nourrir un jeune animal (lapin, cobaye, chien, poulet), dès sa naissance, avec des matières nutritives pures. Par cette dernière expression, j'entenas désigner des produits alimentaires qu'on priverait artifici- 
ellement et complètement des microbes communs.

"Sans rien voulair affirmer, je ne cache pas que j'entreprendrais cette étude, si j'en avais le temps, avec la pensée préconçue que la vie, dans ces conditions deviendrait impossible".

Although the above hypothesis has excited a vast amount of discussion, and although a number of very elaborate experiments have been carried out to test it, the exact relation of the "normal" intestinal bacteria to the animal harboring them is, as yet, by no means definitely settled. Thus, some authorities advance the idea that these bacteria are merely saprophytic forms which, through long association, have become adjusted to conditions in the digestive tract where they exist without exerting any important influence upon the host, unless perhaps in exceptional cases, when they may assume the role of active parasites. Others hold, on the contrary, that their presence is of very great importance in the overgrowing and destroying of the occasional invader, which if allowed to develop unchecked might seriously injure the host, and also in the inhibitory action which they exert unon the common putrefactive intestinal bacteria; while still others assert that, in addition to the function just mentioned, these bacteria not only play an important part in, but are absolutely essential to proper digestion, at least in the higher animals. The first serious attempt to determine by actual experiment the part played by intestinal bacteria in digestion appears to have been made by Nuttall and Thierfelder in their 
classical experiments with guinea pigs. In these experiments the young animals were removed from the mother by Caesarian section and transferreả at once to ingeniously constructed cages where they were kept under absolutely aseptic conditions and supplied with sterile food and water. Under these conditions the authors were able to keep the animals alive for ten days, at the end of which time they were found to have increased considerably in weight. Of the four animals carried through the experiment the increase in weight was found to be $5.5,14$, 16 and 28 grams respectively.

From their data the authors conclude that intestinal bacteria are not essential to digestion and their results have been widely quoted by physiologists as showing that the intestinal bacteria are at most of only minor importance in this process.

The results of these experiments are far from being conclusive, as has frequently been pointed out. Thus, Schottelius was able to keep new-born guinea pios alive for ten days by giving them nothing but sterile water. The same author also found that the intestinal contents of a normal ten-daysold guinea pig weighed from twelve to fifteen grams, and in this case the intestine was not completely filled; while Muttall and Thierfelder, upon examining the pigs at the conclusion of their experiments, found that the colon and expecially the caecum were crammed full, and even greatly distended, with a brow caseous material. Schottelius insists that this 

constantly accumulating mass of undigested food in the intestine would much more than account for the increase in weight reported by Nuttall and Thierfelder and that, instead of increasing in weight, their animals must have been actually starving because unable in the absence of the proper intestinal bacteria to digest the food swallowed.

Pasteur's hypothesis as to the function of intestinal bacteria was, a few years later, again tested experimentally by Schotteluis, who, after carrying out a carefully planned series of experiments, arrived at conclusions decidedly different from those of INuttall and Thierfelder.

In the experiments of Schottelius chickens were used instead of guinea pigs. The artificially incubated eggs were removed and carefully sterilized shortly before the time for hatching and placed for hatching in a specially constructed, sterilized cage, together with sufficient sterile food and water to last throughout the course of the experiment. It was found that chicks hatched and reared in this way, with the total exclusion of bacteria, showed but very little growth; and while they continued to eat ravenously, being apparently unable to satisfy their hunger, they gradually became weaker and after an apparent slight increase for the first few days invariably died, usually within twenty-five days or less after hatching.

In the control cages, which contained chicks treated in exactly the same way except for the addition of a pure culture of a colon bacillus to the food, the young animals developed 

normally in every way and even appeared to show slightly better growth than chicks of the same age which had been allowed to run free in the laboratory as a counter check.

These results are regarded by the author as showing conclusively that intestinal bacteria, especially of the Bacillus coli type, are absolutely essential to proper digestion in chickens and that they doubtless have a similar function in other animals. He summarizes as follows the precise manner in which he thinks the normal bacteria influence the host:

"1. Die Darmbakterien sind notwendig für ảie Ernährung der virbeltiere und für den ienschen;

2. der Nutzen der normalen Darmbakterien besteht:

a) in der Vorbereitung der Ingesta für die Resorption der ivahmungsstoffe

b) in der Reizung der Darmwand zur Auslösung der Peristaltik.

c) in der Überwucherung und Vermichtung pathogener, in den Darm hineingelangter Bakterien.

d) in der Festigung des Körpers gegen pathogene Bakterien und gegen Bakteriengifte."

Similar experiments with the same end in view have been carried out by Horo and by lime. 0. Metxchnikoff on newly hatched tadpoles, Moro working with Pelobates fuscus and lime. Hetschnikoff with Rana temporaria. The results secured by these two workers seem to point to some important digestive function for the intestinal bacteria, although the results in neither case 

appear so conclusive as those given by Schottelius for his work with chicks. In the work of Metschnikoff, for example, the nearly mature embryos were removed aseptically from the gelatinous, enveloping layer and allowed to develop in vessels of sterile water under aseptic conditions. Of forty-nine tadpoles which survived the first few days of the experiment, forty-two developed accidental contamination, and seven remained sterile throughout the experiment.

Although for some reason the mortality was much higher among the non-sterile tadpoles, and although the sterile ones actually lived longest, the development of the sterile ones was much slower than that of the non-sterile, the minimum weight and length of the non-sterile corresponding closely to the maximum of the sterile. These results, however, are regarded by the author as sufficiently conclusive to warrant the assertion that intestinal bacteria are necessary for life and development of tadpoles.

Cohendy, on the other hand, in duplicating the work of Schottelius on sterile reared chicks secured results which he regards as proving conclusively that bacteria are in no way necessary to the normal development of the chicken; and he accounts for the results of his experiments as constrasted with those of Schottelius as being due to the superior technique which he claims to have employed. In the course of this work he was able to keep chicks unaer strictly aseptic conditions for a maximum of forty days during which time the animals de- 

veloped normally, there being no essential difference in grouth and metabolism between the sterile chicks and those kept as a check, and the sterile chicks when placed under natural conditions, after having been kept wholly free from bacteria for a considerable time, developed into perfectly normal adults. His conclusions, which are quite different from those of Schottelius, are: "Ia vie sans microbe est possible pour un vertébré--le poulet--pourpu normalement d'une riche flore microbienne. Cette vie aeptique n'entrâne par elle mejme aucune déchéance de l'organisme."

Insects and other invertebrates have been employed by a number of investigators, as Bogdanow, Woolman, and Delcourt and Guyenot, for working out this same problem. Of these the vork of Delcourt and Guyenot is especially notable, for while no vertebrate has, so far, been carried successfully through its normal life cycle in the total absence of intestinal bacteria, these authors have succeeded in keeping flies of the genus Drosophila for as many as twenty generations under aseptic conditions, finding that growth in the sterile cages was perfectly normal and fully as rapid as in similar but contaminated cages. It also developed that the mortality was remarkably reduced, the eggs almost all hatching from the sterile flies, while in the septic cages whole broods would frequently die. Bogdanow and Woolman, who also worked with flies, chiefly Iucilia caesar and Calliphora vomitoria, both succeeded in rearing these insects with the exclusion of bacteria, but their 

conclusions as to the importance of intestinal bacteria in growth and development are somewhat different. Bogdanow found that, while the larvae would develop under these conditions, growth was greatly retarded, and practically all died at or before pupation although one would occasionally pupate and develop into an undersized fly. He concludes that his experiments show that bacteria, probably those species which decompose protein, are necessary to the normal development of these flies.

Woolman, however, was able to carry the larvae through from sterile eggs to normal adults. During the first few days after hatching the growth of the sterile maggots was noticeably slower than in the septic cages, but later this difference tended to disappear, and when mature the sterile larvae showed practically the length and weight typical for the species, pupated, and developed into perfectly normal adults. This slight check in growth shown by the maggots at first, was attributed by the author to the sterilization of the media at too high a temperature, as it was found that the difference in rate of development largely disappeared when the food was sterilized by the discontinuous method at low temperatures. Maggots hatched from sterile eggs were also treated with cultures of various bacteria, including Bacillus coli, Bacillus proteus valgaris, Bacillus putrificus, and others, in order to determine the part taken by proteolytic bacteria in development, as suggested by Bogdanow, but the infected larvae developed no more rapidy 

than the sterile ones and where Bacillus putrificus was used growth was clearly retarded and the larvae died regularly before reaching the proper stage. Woolman concludes that: "Cet example d'un etre qui, a l'etat naturel, semble vivre en association etroite avec les bacteries, montre clairement que la vie animale est possible en dehors de toute intervention des microorganismes."

It can harảly be doubted that many insects, such as those living parasitically in the body cavity of the host, normally exist during the greater part of their life cycle in the total absence of bacteria; and according to Portier this is also true of the larvae of certain leaf mining micro-lepidoptera. This author found that about $30 \%$ of the Iithocolletis larvae infesting oak, elm, etc., were wholly free from bacteria and that practically $100 \%$ of the larvae of a species of Nepticula infesting the rose and which do not void the excrement on the exterior of the mine were also sterile.

Notwithstanding the direct experimental evidence in support of a digestive function for intestinal bacteria, as advanced by Schottelius and others, the view appears to be generally held by physiologists, largely on account of the characteristic limitation of the different classes of intestinal bacteria to certain well defined regions of the digestive tract, that in the higher animals at least, the actual solution of the nutrient materials in the food, in the absorptive portion of the gut, is performed chiefly if not entirely by the 

digestive secretion produced by the animal itself and that the chief function of the "normal" intestinal bacteria consists, not in any direct action on the food in preparing it for resorption, but rather in preventing indirectly the undue multiplication of injurious forms which are continually invading the intestine of the host.

There appears to be little question that the normal intestinal bacteria of higher animals, such as the groups represented by Bacillus coli. Bacillus (lactis) aerogenes, and Bacillus bifidus, do possess definite antagonistic properties for the less perfectly adapted species, although the exact mechanism of this antagonism has been explained in a number of different ways. Some would account for this phenomenon as being due largely to overcrowding, with consequent starvation of the less hardy species. The normal forms being constantly present in the intestine in large numbers, and well adapted to vigorous growth in certain well defined regions, would naturally be better able to appropriate any nutrient materials which had escaped resorption by the host than those forms which only occasionally invade the intestine.

The various products of fermentation produced by these bacteria, especially the organic acids, are also held to be of very great importance in this same connection.

Another and apparently an exceedingly important factor in this antagonism lies in the production by these organisms of definite toxin-like bodies, the "autotoxins" of Conradi and 
Kurpjuweit, which in some way clearly exert a restraining influence upon the development of many bacterial species.

These latter substances, which have been carefully studieả especially for Bacillus coli, by Eijkman, as well as by Conradi and Kurpjuweit and others, are regarded by these authors as mainly responsible for the familiar weakening and ultimate death of bacteria in old cultures which was formerly held to be due chiefly to a gradual exhaustion of the nutrient materials, resulting in death by starvation.

It was found by Rijkman, and later by Conradi and Kurpjuweit, that such an old and apparently exhausted culture could again be made to support growth by inactivating the toxins, as by heating to $60^{\circ} \mathrm{C}$. or by filtering through porcelain, and that these same toxins were constantly present in normal feces, where they could be detected in very high dilutions, even as great as $1--10,000$.

These "autotoxins", as the name implies, affect the organism producing them as well as various other species, although, as is suggested by Conradi and Kurpjuweit, under normal conditions in the intestine the obligate species, as Bacillus coli, would doubtless develop a certain amount of immunity to their own poison which would not be shared by other transient forms.

According to Kohlbrugge there is an "Auto sterilization" of the small intestine in man and the higher animals generally; and normally the bacteria which occur in this part of the di- 
gestive tract are found only in the food masses, so that when the intestine is emptied the bacterial flora consequently disappears, leaving the empty intestine practically sterile. He also found that even after prolonged fasting the caecum, that portion of the digestive tract characterized by the greatest development of bacteria of the Bacillus coli type, always contained quantities of this organism; and he insists that the caecum and the vermiform appendix, instead of being the useless, vestigial organs that they are commonly considered, are in reality of the greatest importance to the animal possessing them in functioning as a natural and safe culture place for a vast reserve supply of the colon bacillus. 
SUMMARY

The caeca of the heteroptera are apparently vestigial organs which are in process of elimination, and which have probably lost their digestive function.

These apparently functionless, vestigial organs have become the seat of a remarkable bacterial infection which is comparable in many ways in the well known infection by Bacilius coli of somewhat analagous organs in the higher vertebrates, and this infection is also transmitted regularly from generation to generation through the egg.

As a result of this caecal infection in the lieteroptera, the development of other bacteria and protozoa which would naturally be expected to invade the alimentary canal of these insects is clearly inhibited; and not only are these forms restrained in their development, but they aro apparently killed outright, so that the alimentary canal of these insects is practically ${ }_{A}$ except for the normal caecal bacteria.

The caecal bacteria are apparently of no direct aid to digestion in the insects harboring them. 


\section{BIOGRAPHICAL}

Hugh Glasgow received the degree of Bachelor of Arts in Entomology from the University of Illinois in 1908. He received a scholarship in entomology in the Graduate School of the University of Illinois for the year 1908-1909, was a fellow in entomology during the years 1909-1911, and assistant in entomology during the years 1911-1913.

He is a member of Sigma Xi, Illinois Chapter; of the American Association for the Advancement of Science; of the lllinois Academy of Science; and the Entomological Society of America. 
PLATE I

Figure 1

Peribalus limbolarius Stäl.

l'igure 2

Thyrecoris unicolor Pal. Beauv. (male)

Figure 3

Anasa tristis De G. 

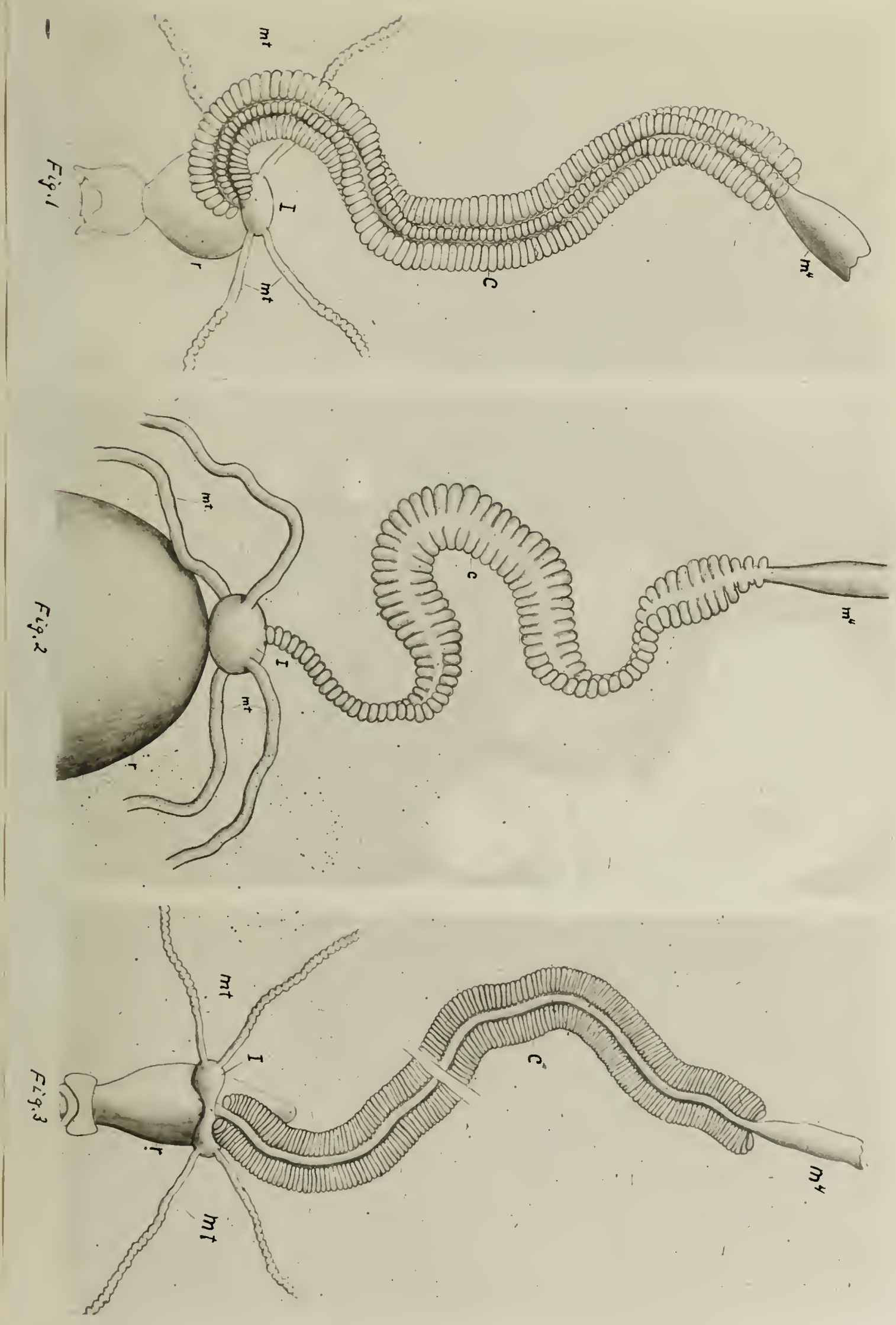
PLATĩ II

Fi gure 1

Myodocha serripes Oliv.

Figure 2

Pamere basalis Dallas

wigure 3

Jalysus spinosus Stäl. 

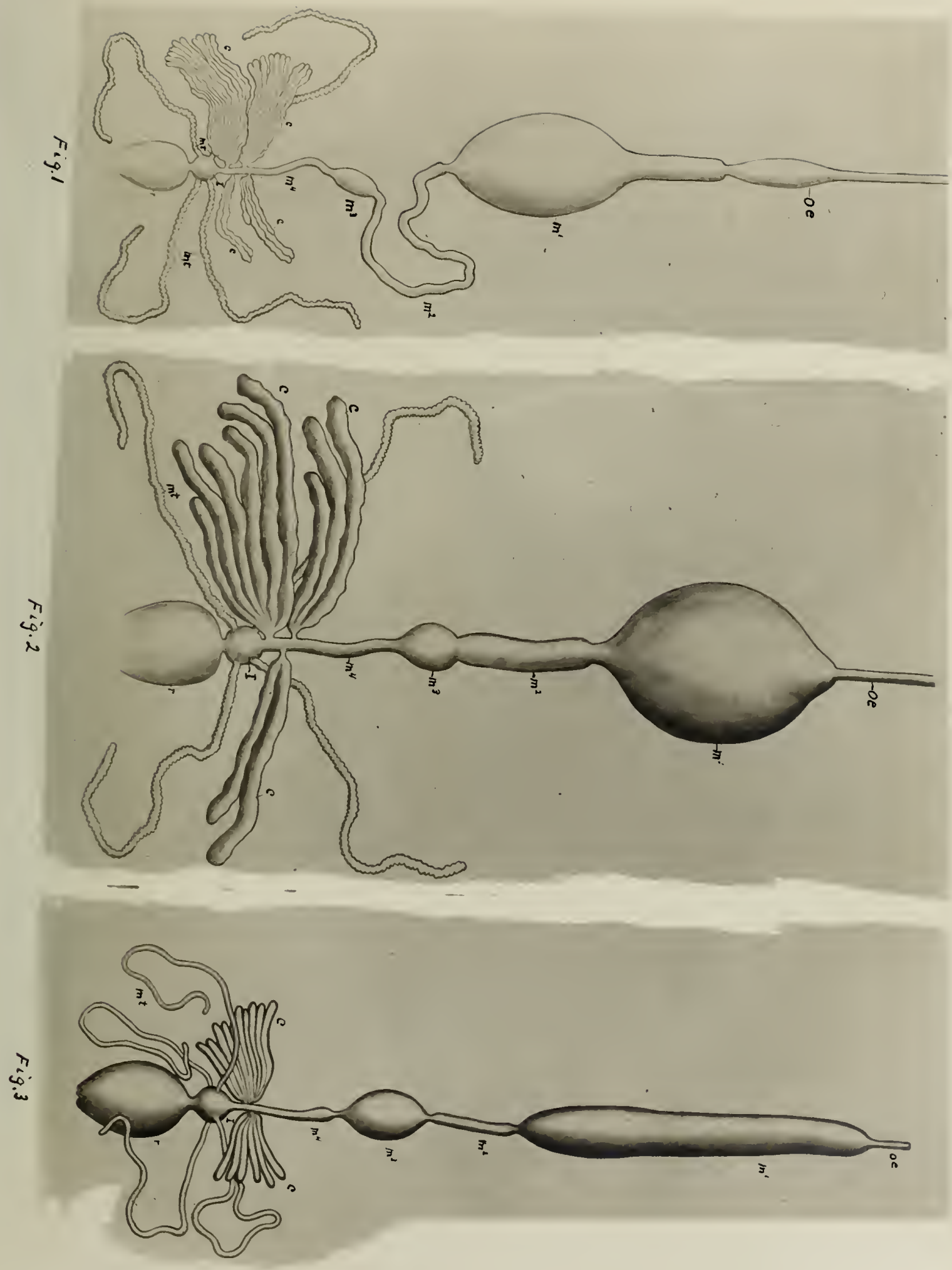
PLATE III

Figure 1

Dysdercus suturellus Schaeff.

Elgure 2

Phlegyas abbreviata Uhl. (male)

Figure 3

Phlegyas abbreviata Uhl. ( female) 

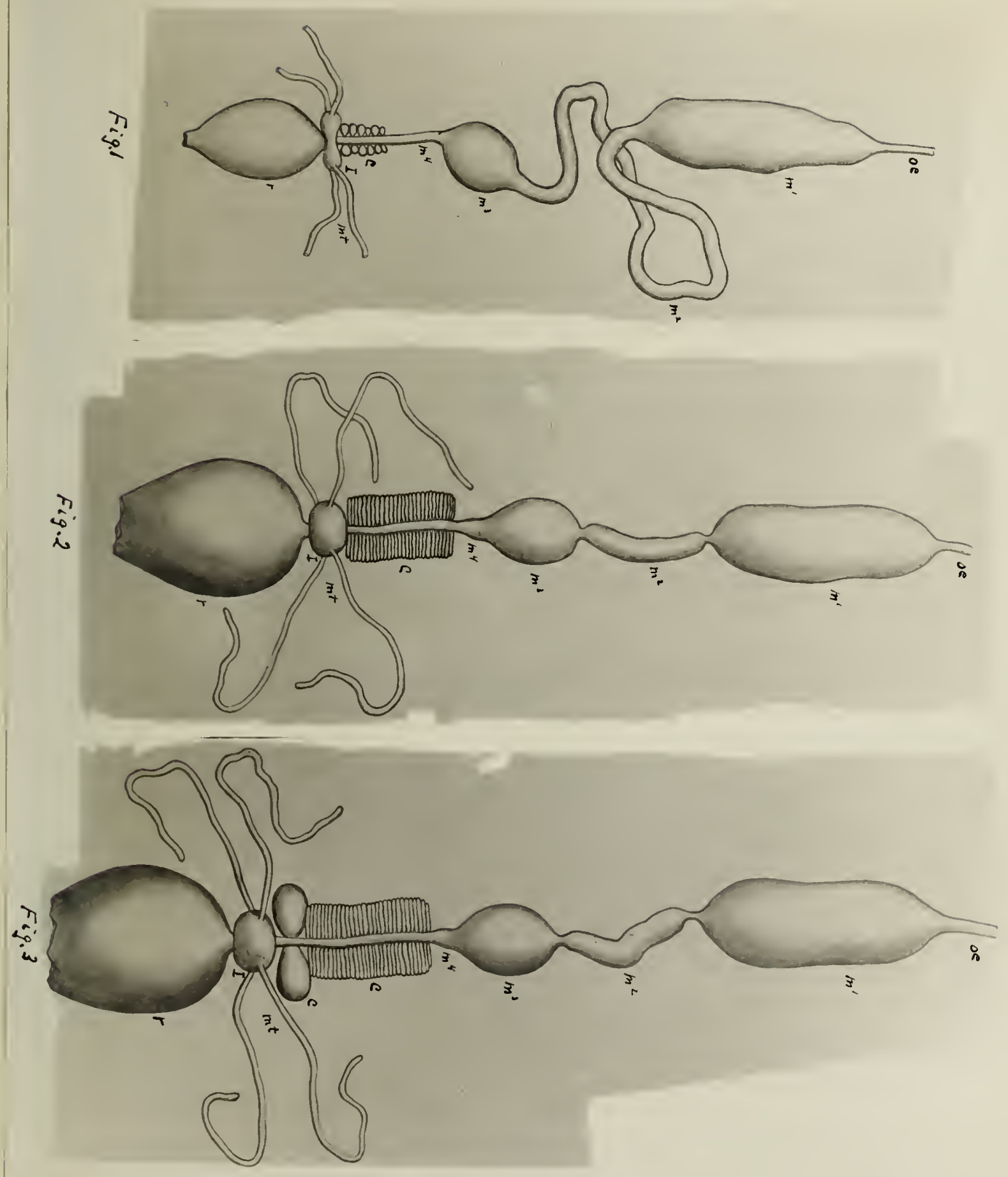
PLATE IV

Figure 1

Peribalus limbolarius Stäl.

Higure 2

of Thyrecoris unicolor Pal. Beauv.

Figure 3

Podisus maculiventris Say. 

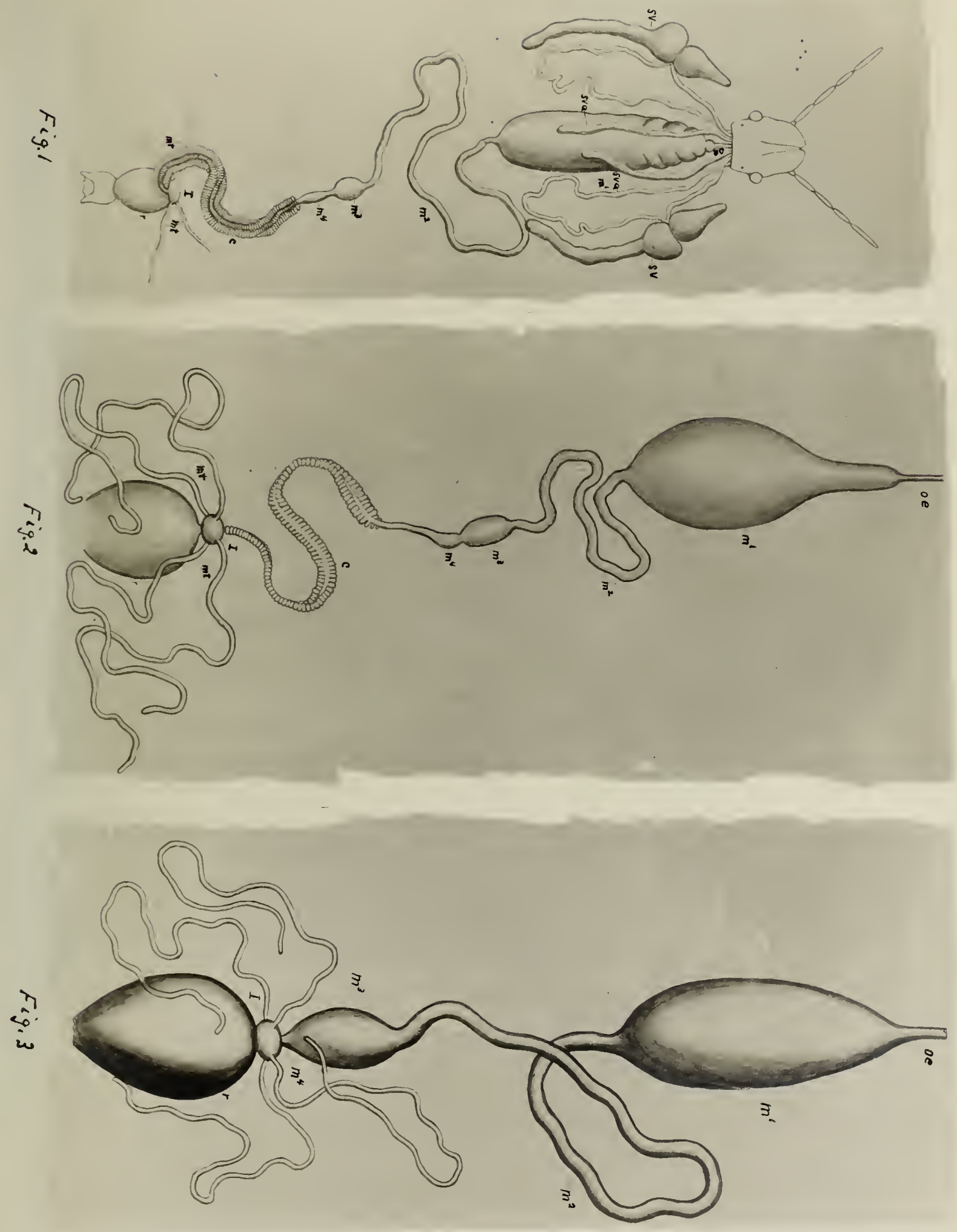
PLATE V

Figure 1

Blissus leucopterus Say.

inigure 2

Oedancala donalis Say.

Figure 3

Homoemus proteus Stal. 

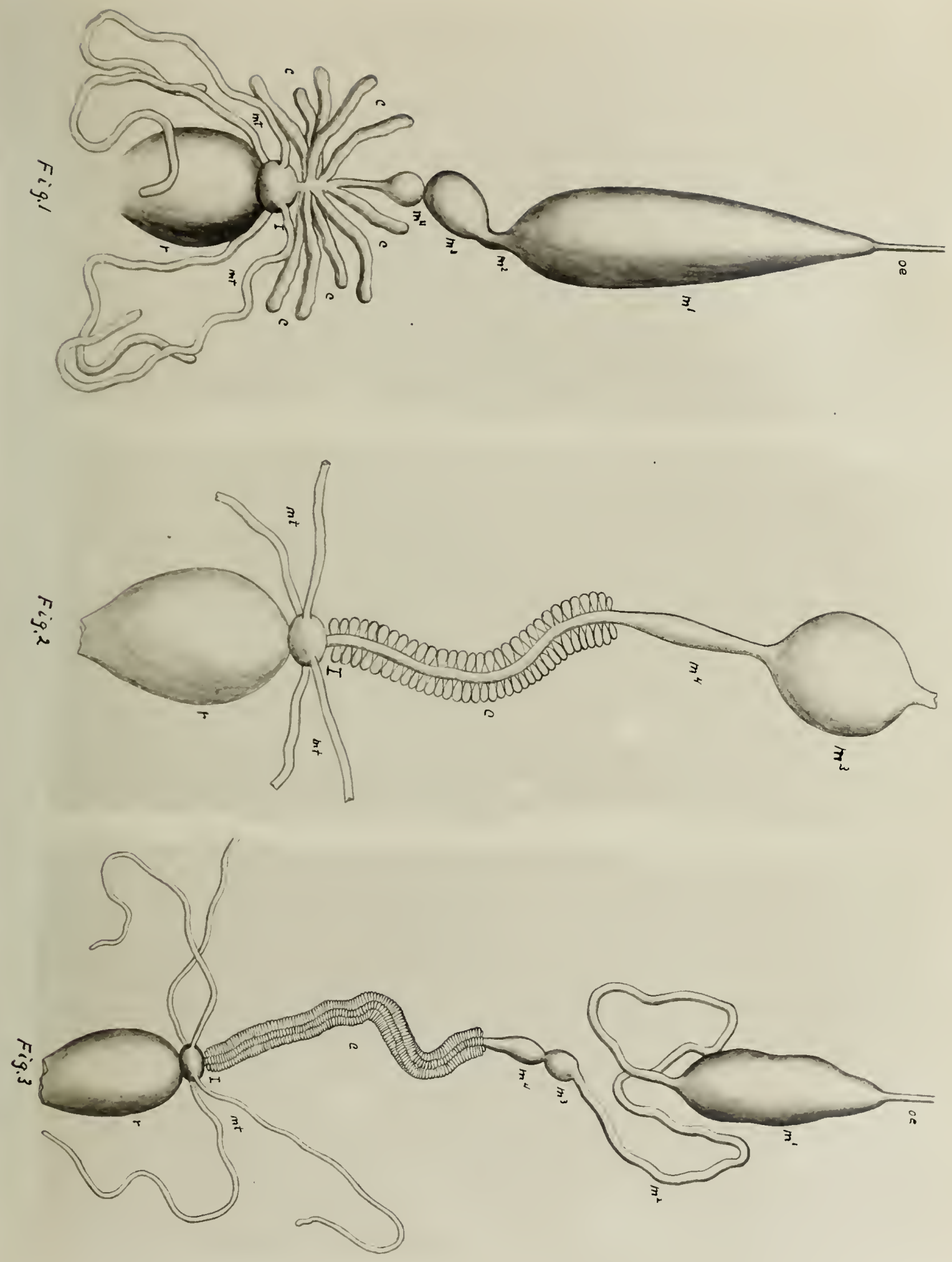
PLATE VI

i'igure 1

Largus cinctus Schaeff.

Figure 2

Dysdercus suturellus Schaeff. (male)

\section{Eigure 3}

Dysdercus suturelius Schaeff.

(female) 

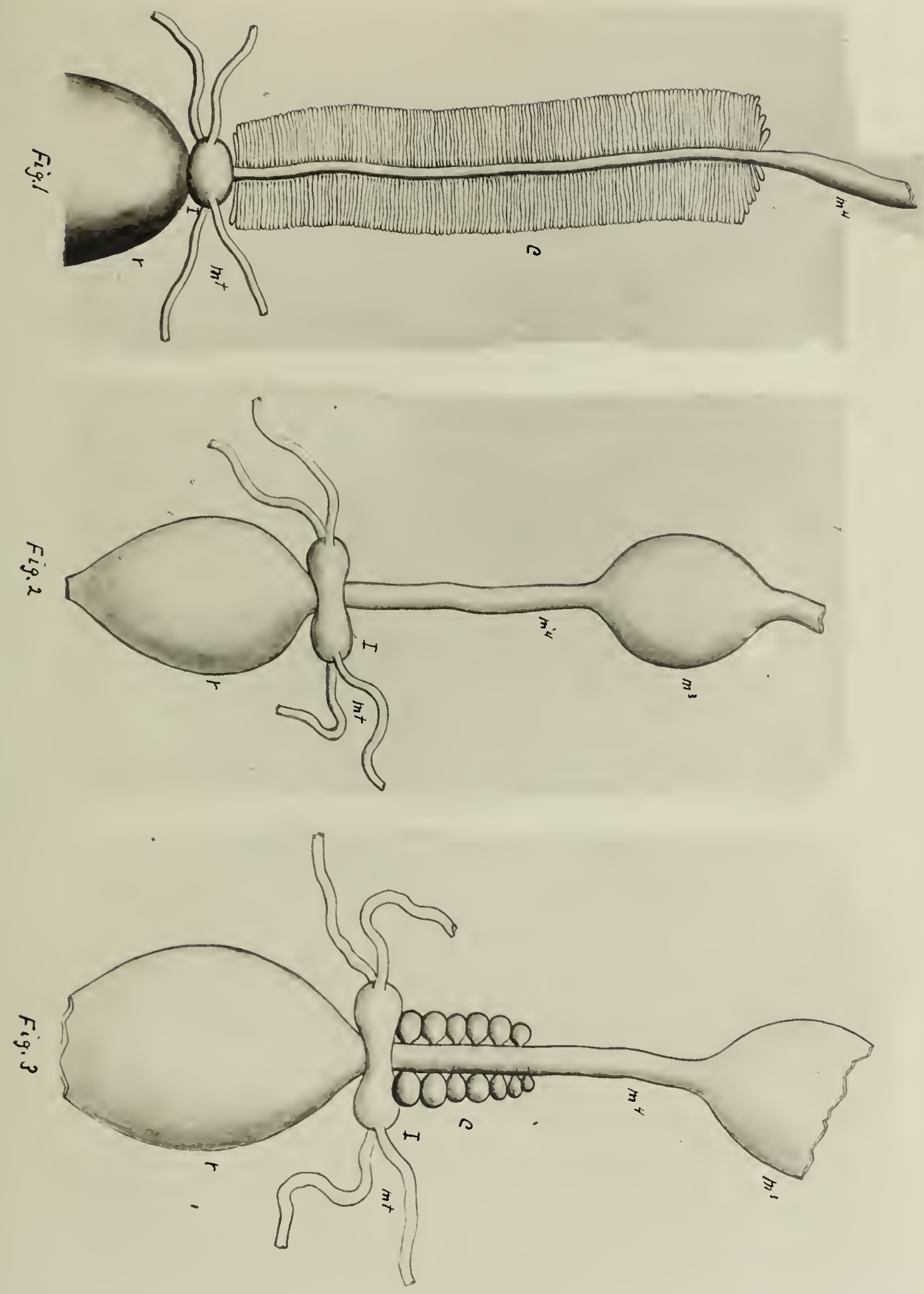
PLATE VII

Pigure 1

Myodocha serripes Oliv.

Figure 2

Microtoma carbonaria

Eigure 3

Peribalus limbolarius Stål. 

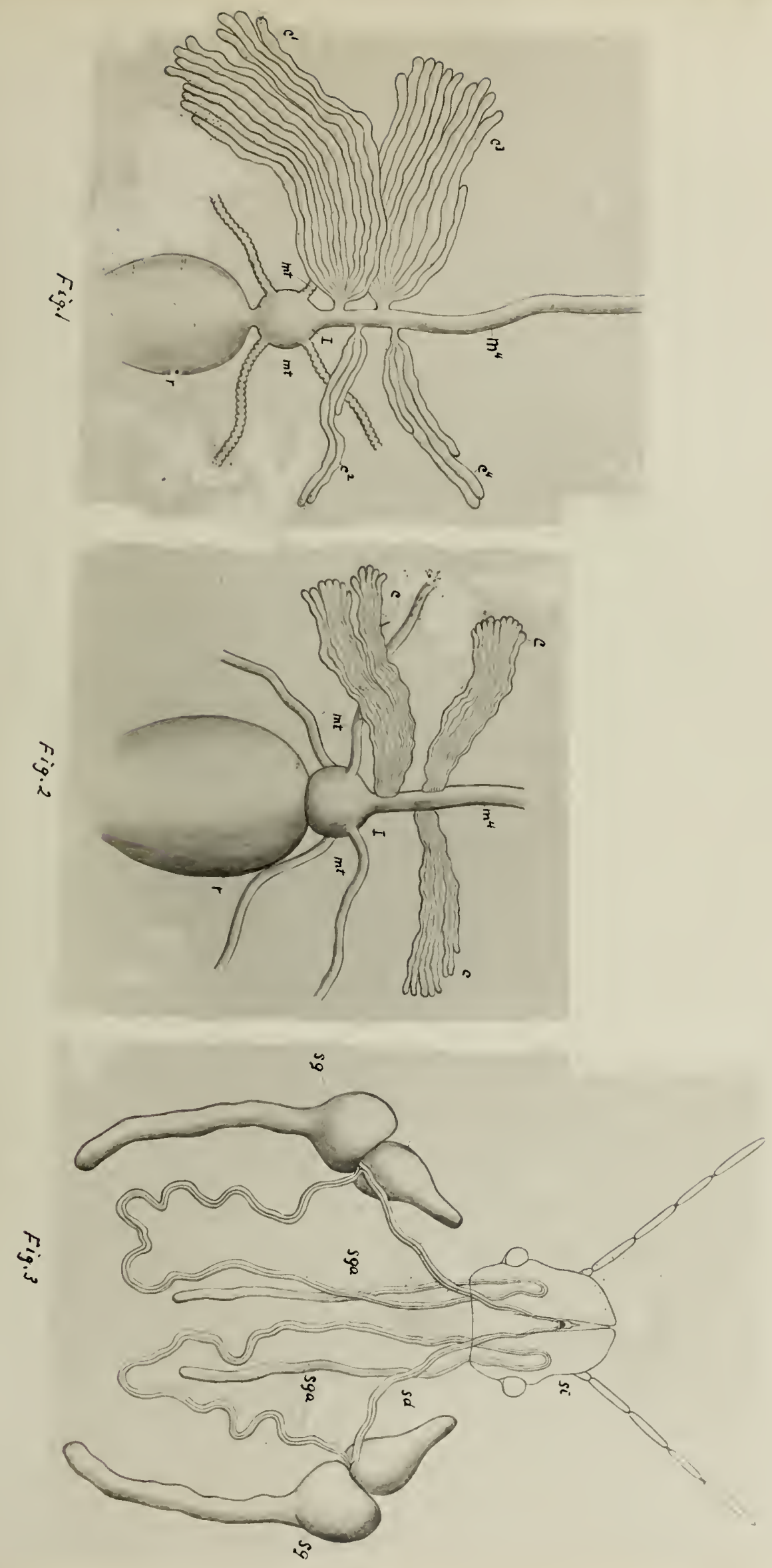
PLATE VIII

Figure 1

Blissus leucopterus Say.

(Caeca in normal position)

Figure 2

Blissus leucorterus Say.

(Intestine stretched to show grouping of caeca) 

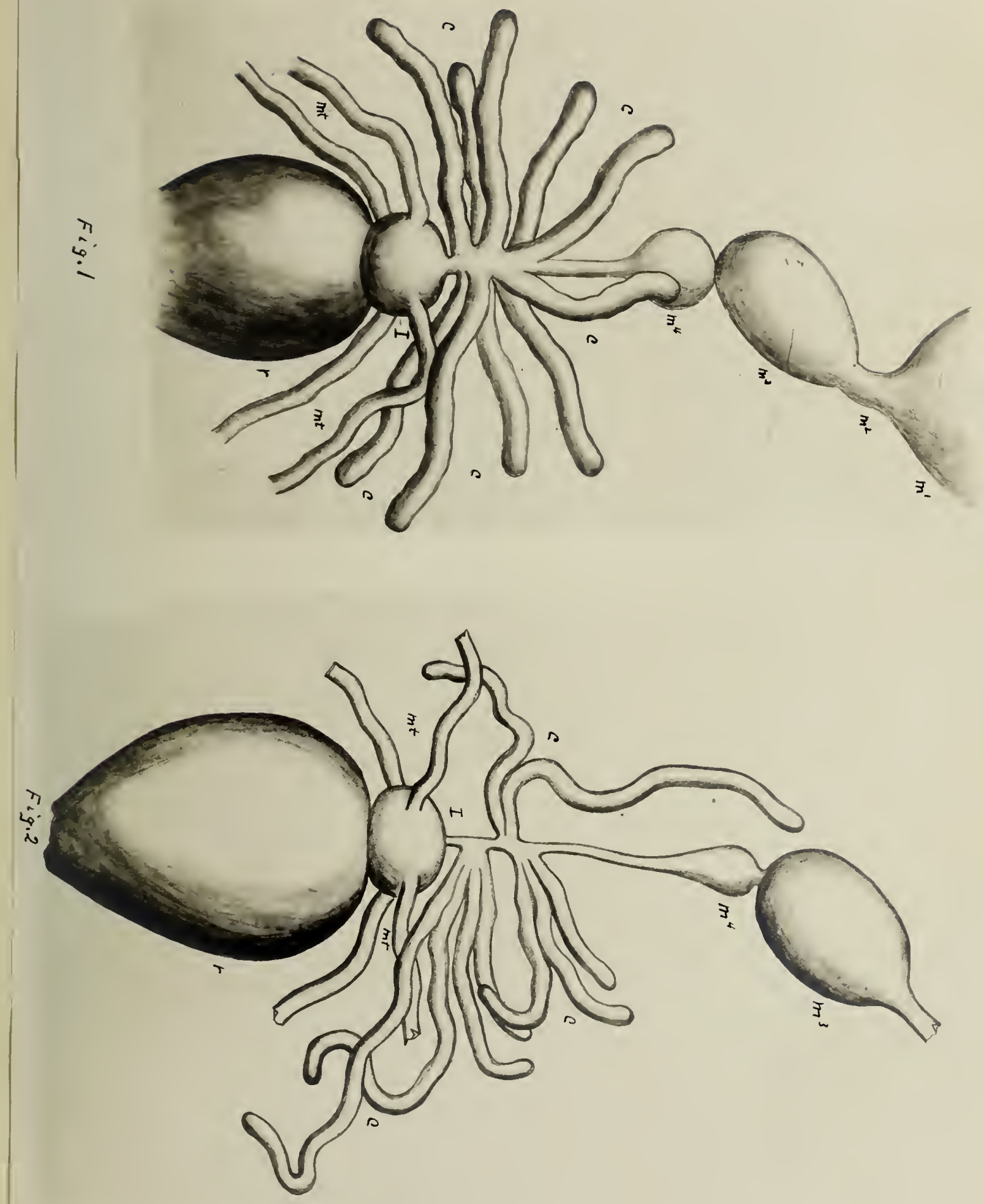

